The perceived association between audit rotation and audit quality: Evidence from the UAE

John K. Malagila ${ }^{\mathbf{a}}$, Ganga M. Bhavani ${ }^{\mathbf{b}}$ and Christian Tabi Amponsah ${ }^{\mathbf{c}}$

${ }^{a}$ Centre for Research in Accounting, Accountability and Governance

Department of Accounting, Southampton Business School

University of Southampton

Southampton, UK

${ }^{\mathbf{b}}$ School of Business

Manipal University

Academic City, Dubai, UAE

${ }^{c}$ Yorkville University

Vancouver Campus

Vancouver, British Columbia, Canada

\begin{tabular}{|r|l|}
\hline Journal: & Journal of Accounting in Emerging Economies \\
\hline Manuscript ID: & JAEE-08-2018-0082.R2 \\
\hline Manuscript Type: & Research Paper \\
\hline Status: & Accepted for publication on 25-Feb-2020 \\
\hline DOI: & $10.1108 /$ JAEE-08-2018-0082 \\
\hline
\end{tabular}




\title{
The perceived association between audit rotation and audit quality: Evidence from the UAE
}

\begin{abstract}
Purpose: The purpose of this paper is to explore the perceived association between audit rotation (AR) and audit quality (AQ) using respondents from a sample of audit firms operating in a developing economy, the United Arab Emirates (UAE). The paper addresses the following research question: How do UAE auditors perceive the association between various forms of $A R$ and $A Q$ ?
\end{abstract}

Design/Methodology: We collected perception data from a sample of UAE auditors using a questionnaire, and applied several non-parametric statistical techniques to analyze the data, and to answer five exploratory research questions on the perceived association between various forms of $\mathrm{AR}$ and $\mathrm{AQ}$.

Findings: The findings suggest that the UAE auditors in our sample did not perceive the association between individual types of AR and AQ as significantly different, and that AR in general is essential for AQ improvement and enhances trust in the audit process. Similarly, we find more support for the perception that medium audit tenure is associated with a lower impairment effect on auditor independence. Furthermore, we find no significant differences in perception based on gender, but younger/less experienced professionals and professionals in self-employed practices and small audit firms (compared to other demographics) significantly perceived AR enforceability and AT length to be associated with AQ. Our findings help to enrich our understanding of the perceived AR-AQ association in a relatively new context and less researched audit area in a developing economy.

Originality/Value: Although lively debates on the question of $A R$ and $A Q$ within the accounting, finance, investment professions and in the financial media continue, there has been relatively limited knowledge and a dearth of empirical studies on this question in most developing economies. Being the first attempt in the country - the UAE, this study contributes towards addressing this gap in empirical knowledge by exploring the perceived association between various forms of AR and AQ in a developing economy.

Keywords Auditor rotation, Auditor tenure, Audit quality, Auditor efforts, Auditor trust, United Arab Emirates 


\section{INTRODUCTION}

Debate on auditor rotation (AR) has persisted for several decades and variously emphasizes voluntary versus mandatory auditor rotation, the ideal duration of audit tenure, and whether to rotate an audit firm, team, partner or individual auditor (e.g., Arel, Brody, and Pany, 2005; Azizkhani, Daghani, and Shailer, 2018; Johnson, Khurana, and Reynolds, 2002). High profile scandalous accounting cases often attract scrutiny of audit firm-client relationships and their effect on auditor independence (AI) and audit quality (AQ) (Arel et al., 2005; Johnson et al., 2002). Concerns have been raised about the effect of AR (or a lack of it) on AI, and the need for regulatory actions such as imposing mandatory auditor rotation (MAR) (Firth, Rui, and $\mathrm{Wu}, 2012$; Johnson et al., 2002). While in recent years many developing countries have implemented laws and regulations that require AR of some sort, the extant literature on the AR-AI-AQ association is arguably still limited (Adeyemi and Okpala, 2011; Azizkhani et al., 2018; Ebimobowei and Keretu, 2011; Firth et al., 2012). There are also only few such studies in the Arab Middle East (e.g., Azizkhani et al., 2018). In this paper, we aim to contribute to this literature by exploring the perceived association between AR and AQ in a developing country, the United Arab Emirates (UAE).

Historically, governments and regulators around the world have been interested in implementing MAR to enhance AI (Arel et al., 2005; Bowlin, Hobson, and Piercey, 2015; Cameran, Prencipe, and Trombetta, 2016; European Commission, 2010). To date, studies on whether and how various forms of AR affect AQ show mixed results. For example, some studies indicate that medium to long audit tenure is associated with higher AQ (Johnson et al., 2002; Myers, Myers, and Omer, 2003), whereas others find that AQ diminishes with longer audit tenure (Davis, Soo, and Trompeter, 2009). In 2010, the European Commission released a Green Paper for public consultation, which proposed a MAR to be considered (European Commission, 2010). Responses from the consultation process showed mixed results as well, with more respondents rejecting the proposal, and calling for more research on the pros and cons of MAR (European Commission, 2011).

We had two major motivations to write this paper. The first is the lack of consensus in the literature on the effect of $\mathrm{AR}$ on $\mathrm{AQ}$, which provided the opportunity to ask similar questions in new contexts in which auditing is emerging as a prominent tool for attesting to firms' accountability and stewardship. In recent years, the UAE has become one such new context (Arnold, 2014; Doward, 2018; PwC, 2017; Sambidge, 2014; The CFO, 2015; UAE, 2015; Venkataraman, 2018). Furthermore, the increasing interest in improving AQ in the 
UAE is associated with the perception that auditors in the UAE could do more than financial auditing by helping in the fight against fraud, embezzlement and economic/financial crimes that take place in UAE firms (Halbouni, 2015; KPMG, 2014; PwC, 2017; Sambidge, 2014). A 2014 business news reporting of a survey by PricewaterhouseCoopers (PwC) indicated that over 1 in 4 UAE firms are victims of fraud (Arnold, 2014). Ironically, the audit profession is also facing some criticisms and is under pressure to clean up its own practices. The criticisms are raised against alleged irregularities and unlawful, unprofessional and unethical behavior/practices of audit firms, including some highly reputable audit firms (Doward, 2018; Venkataraman, 2018).

Second, although there is a continuing lively debate on the question of the AR-AQ relationship within the finance/accounting profession and the financial media, relatively limited knowledge exists and there is a dearth of empirical studies on this question in most developing economies (Adeyemi and Okpala, 2011; Ebimobowei and Keretu, 2011; Firth et al., 2012). Therefore, we seek to contribute towards addressing this gap by exploring the perceived association between various forms of AR and AQ in a developing economy, the UAE.

The rest of this paper is organized as follows. Section 2 discusses the UAE audit regulatory framework and outlines the main reasons for choosing the UAE as a research setting. Section 3 provides the literature review and develops the exploratory research questions addressed in the current study. We present research methods in Section 4, following by results and discussion in Section 5, while Section 6 summarizes and concludes the study.

\section{THE AUDIT REGULATORY FRAMEWORK IN THE UAE}

The audit regulatory framework in the UAE is made up of five bodies that are directly or indirectly engaged with or influence the regulation of audit activities. Table 1 presents the UAE audit regulatory structure by listing the current regulatory agencies and summarizes their roles, jurisdictions, applicable laws and relationships with other agencies. It indicates that the regulation of auditing in the UAE private sector is significantly under governmentcontrolled agencies such as the Abu Dhabi Accountability Authority (ADAA), the outgoing Financial Audit Department (FAD) and the incoming Financial Audit Authority (FAA). 
Table 1: UAE Audit Regulatory Structure

\begin{tabular}{|c|c|c|}
\hline $\begin{array}{l}\text { Regulatory } \\
\text { Agency }\end{array}$ & Audit Related Roles and Jurisdiction & $\begin{array}{l}\text { Applicable Laws and Relationship with other } \\
\text { Agencies }\end{array}$ \\
\hline $\begin{array}{l}\text { Financial Audit } \\
\text { Department } \\
\text { (FAD) }\end{array}$ & $\begin{array}{l}\text { - Roles: Supreme Audit Institution (SAI) of Dubai - Conducts regular financial, } \\
\text { information systems, and performance audits. } \\
\text { - Jurisdiction: All government departments, public corporations, companies in } \\
\text { which the government shareholding is above } 25 \% \text {, organizations for which the } \\
\text { government provides a financial subsidy, and any other body where an audit is } \\
\text { commissioned by His Highness the Ruler of Dubai. } \\
\text { - Available from http://www.faa.gov.ae/en/AboutDepartment/Pages/default.aspx } \\
\text { [Accessed on 22/02/2019] }\end{array}$ & $\begin{array}{l}\text { - Law No. (1) of 1995, amended by Law No. (5) of } \\
2000 \text {. Subsequent amendment by Law No. (3) of } \\
2007 \text { and Law No. (8) of } 2010 \text { as amended. } \\
\text { - FAD will soon be replaced by FAA. At the time } \\
\text { of paper submission, the replacement of FAD by } \\
\text { FAA was still under transition. }\end{array}$ \\
\hline $\begin{array}{l}\text { Financial Audit } \\
\text { Authority } \\
\text { (FAA) }\end{array}$ & $\begin{array}{l}\text { - Role: SAI of Dubai (to replace FAD) - Reviews and audits unified financial } \\
\text { statements (FS), issues regulations that govern the preparation/presentation of } \\
\text { government FS and reports and the general final account. Investigates any } \\
\text { financial or administrative irregularities, identifies the reasons, and takes } \\
\text { appropriate action. } \\
\text { - Jurisdiction: Entities and departments under the FAA (Same as those under the } \\
\text { outgoing FAD) } \\
\text { - According to Staff Report (2018) }\end{array}$ & $\begin{array}{l}\text { - Law No. (4) of 2018, and Decrees No. (14) and } \\
\text { (15). This law will soon replace Law No. (8) of } \\
2010 \text { as amended. FAA replaces FAD. } \\
\text { - Liaises with federal, regional, and international } \\
\text { authorities, sign agreements with external } \\
\text { organizations, and allowed to become a member } \\
\text { of regional and international organisations. }\end{array}$ \\
\hline $\begin{array}{l}\text { State Audit } \\
\text { Institution (SAI) }\end{array}$ & $\begin{array}{l}\text { Role: SAI of the UAE - Controller and auditor of the UAE government, works to } \\
\text { preserve public funds, improve governance tools, performance level, } \\
\text { strengthening principles of transparency and accountability, including the fight } \\
\text { against fraud and corruption in the government. } \\
\text { - Jurisdiction: All government departments and federal government institutions. } \\
\text { - Available from: http://saiuae.gov.ae/en/Pages/mission.aspx [Accessed on } \\
\text { 13/3/2019], also see Ibrahim (2010). }\end{array}$ & $\begin{array}{l}\text { Federal Law No. (7) of } 1976 \text { according to Article } \\
\text { (136) of the Constitution, amended and } \\
\text { superseded by the Federal Law No. (8) of } 2011 . \\
\text { An independent authority reporting to the UAE } \\
\text { Federal National Council. The SAI's strategic } \\
\text { partners are: INTOSAI - International } \\
\text { Organisation of Supreme Audit Institutions, } \\
\text { ARABOSAI - Arab Organization of Supreme } \\
\text { Audit Institutions, and the Secretariat General of } \\
\text { the Cooperation Council for the Arab States of } \\
\text { the Gulf. }\end{array}$ \\
\hline
\end{tabular}




\begin{tabular}{|c|c|c|}
\hline $\begin{array}{l}\text { Regulatory } \\
\text { Agency }\end{array}$ & Audit Related Roles and Jurisdiction & $\begin{array}{l}\text { Applicable Laws and Relationship with other } \\
\text { Agencies }\end{array}$ \\
\hline $\begin{array}{l}\text { Dubai Financial } \\
\text { Services } \\
\text { Authority } \\
\text { (DFSA) }\end{array}$ & $\begin{array}{l}\text { Role: Dubai's financial services authority - develops, administers and enforces } \\
\text { financial services regulations for the DIFC. Established as an independent } \\
\text { regulator of financial services to promote quality audits, detection and prevention } \\
\text { of money laundering, and improve assurance and transparency at the DIFC. } \\
\text { - Jurisdiction: Authorizes and registers institutions and individuals who wish to } \\
\text { conduct financial services in or from the DIFC. } \\
\text { - Available from: https://www.dfsa.ae/en/About-Us/Our-Purpose [Accessed on } \\
\text { 13/3/2019] }\end{array}$ & $\begin{array}{l}\text { Regulatory Law 2004, Markets Law 2012, Law } \\
\text { Regulating Islamic Financial Business 2004, } \\
\text { Collective Investment Law } 2010 \text { and the } \\
\text { Investment Trust Law } 2006 \text {. } \\
\text { - Works closely with the UAE Central Bank. }\end{array}$ \\
\hline $\begin{array}{l}\text { Abu Dhabi } \\
\text { Accountability } \\
\text { Authority } \\
\text { (ADAA) }\end{array}$ & $\begin{array}{l}\text { - Role: An independent accountability authority - Provide independent and } \\
\text { objective assurance and advisory services to improve performance and promote } \\
\text { accountability and transparency, to ensure public entities' resources and funds are } \\
\text { collected, managed, and expended efficiently, effectively, economically and } \\
\text { ethically, to ensure accuracy of financial reports and compliance of public entities } \\
\text { with laws, rules, regulations and governance guidelines, train and qualify UAE } \\
\text { National University graduates and establish training centres, and conduct } \\
\text { investigations of complaints and any other violations referred to or that come to } \\
\text { ADAA's attention. } \\
\text { - Jurisdiction: Abu Dhabi local departments, councils and authorities, institutions } \\
\text { and companies in which the government ownership is equivalent to or exceeds } \\
\text { 50\%, and subsidiaries. } \\
\text { - Available from: http://www.adaa.abudhabi.ae/en/Pages/default.aspx } \\
\text { on 13/3/2019] }\end{array}$ & $\begin{array}{l}\text { - Law number } 14 \text { of } 2008 . \\
\text { - Works closely with the Abu Dhabi government, } \\
\text { and Abu Dhabi General Services Company } \\
\text { (Musanada) }\end{array}$ \\
\hline
\end{tabular}


The Dubai Financial Services Authority (DFSA) is an independent private sector-based regulatory agency. The DFSA was established, among other reasons, to promote the quality of audit services at the Dubai International Financial Centre (DIFC).The DIFC was established in 2004 as a special economic zone in Dubai, and a financial hub for the Middle East, Africa and South Asia markets (https://www.difc.ae/).

One of the crucial issues in audit regulation is the role of AR in improving AQ (Daniels and Booker, 2011). A study of 37 countries found that most of the developing economies have laws and regulations on AR or, because AR is favorably perceived by users of audited financial reports, firms opt to voluntarily practice AR (Cameran, Negri, and Pettinicchio, 2015). The UAE is not an exception. UAE audit requirements are provided in the recently enacted Federal Law No. 2 of 2015 (w.e.f. 01/07/15). The current law replaced the old Federal Law No. 8 of 1984 (UAE, 2015). The new law states that 'The General Assembly (of a firm or organization) may appoint one or more auditors for one renewable year, provided that such term shall not exceed three successive years ...' (Article 243 (2)). This is one of the new audit provisions, which was not in the old law. Effectively, this provision introduces MAR after every three years of successive appointments of the same audit firm.

The ADAA introduced MAR in 2014. As indicated in Table 1, ADAA is an independent body mandated to oversee transparency and accountability in the Abu Dhabi Government. According to the ADAA, it is now mandatory for public entities and stateowned enterprises in Abu Dhabi to rotate audit firms after every four years (ADAA, 2014). The ADAA (2014) argues that "to ensure a better independence, statutory auditors cannot be retained for a period exceeding four consecutive years". In addition, entities under the Abu Dhabi government are also required to comply with the federal law (UAE, 2015). Overall, while this background information on auditing in the UAE shows that voluntary audit rotation (VAR) has a long history in the UAE, MAR is a relatively new phenomenon.

We have three reasons for choosing the UAE as our research setting. First, until recently, the UAE has been a tax-free regime with changes to the tax rules taking effect from January 2018 (CNBC, 2017; Saderuddin and Barghathi, 2018). The UAE now imposes a 5\% Value Added Tax (VAT) on most goods and services to boost its revenue base (CNBC, 2017; Saderuddin and Barghathi, 2018). This change from a tax-free to a tax environment poses two new threats or challenges to the quality of the audit function in the UAE. First, the increase in demand for non-audit/consulting services such as the preparation of tax returns will potentially increase auditor-manager cooperation (Abdullah, Naser, and Al-Enazi, 2017; Saderuddin and Barghathi, 2018). Consequently, as found by Kowaleski, Mayhew, and 
Tegeler (2018), in situations where managers (of audit firm or audit client) prefer low AQ (for example in a recent scandal involving one of the Big 4 audit firms and reported by Doward (2018)), increased auditor-manager cooperation will decrease AI, hence AQ. Second, in the new VAT regime, companies are likely to start tax planning as a way to minimize their tax burden (Frunza, 2019; Saderuddin and Barghathi, 2018; Stanley-Smith, 2018). Tax planning may involve the practice of opportunistic earnings management, for example, to avoid or evade VAT expenses (Frunza, 2019; Stanley-Smith, 2018). This will likely increase complexity and challenges in performing audit assignments.

Recently, Saderuddin and Barghathi (2018) examined VAT impact on the audit profession and the economy in the UAE from the auditors' perspective. They found that most auditors believed that, in the long run, VAT implementation will improve the UAE's economic growth. However, they found mixed perceptions of whether the audit profession will be affected. The Big 4 auditors' view was that VAT implementation will not affect AQ, while the non-Big 4 auditors believe that AQ could be affected due to increased responsibilities and work related to VAT compliance by their audit clients. As researchers, this provides us with a research opportunity to contribute to empirical knowledge by specifically exploring perceptions of AQ in the UAE within these tax-related changes.

Second, after many years of deliberating the significance of MAR in improving AQ, the UAE recently introduced a three-year MAR and a four-year MAR at the federal level (The CFO, 2015; UAE, 2015) and at the Abu Dhabi governance level (ADAA, 2014), respectively. As VAR is not new in the UAE, we argue that it is significant to explore, and take stock of the role of AR in improving AQ now, when the UAE is embarking on MAR. Additionally, the significance of exploring the perceived effect of AR on AQ in the UAE is also increased by the fact that the UAE business community does not seem to always share the view held by the UAE government/regulators that MAR improves AQ. A recent roundtable conference on the changing role of audit conducted by Grant Thornton indicated there were many UAE participants/organizations that voiced their opposition to and concerns about whether MAR would help to improve AQ in the UAE (Grant Thornton, 2015; The CFO, 2015). The opposition against MAR is based on, among other reasons, high new engagement set-up costs to audit firms, costs to audit clients in supporting a new audit firm to learn the audit client's procedures, and barriers to building effective audit-firm and client working relationships (Ewelt-Knauer, Gold, and Pott, 2013). The current study aims to contribute to empirical knowledge on this aspect in the UAE. 
Third, although many studies have explored the effect of AR on AQ, arguably there are only limited efforts in comprehensively investigating the effect of a combination of various forms of AR on AQ. The various forms of AR could be categorized based on AR levels (i.e. $\mathrm{AR}$ at audit firm, team or individual/partner levels), audit tenure (i.e. short, medium or long audit tenure) and AR enforceability (i.e. VAR or MAR).

Therefore, consistent with this background to the UAE, AR regulatory framework and the reasons we argued for choosing the UAE as our research context, the following Section 3 develops the exploratory research questions addressed in this paper.

\section{DEVELOPING EXPLORATORY RESEARCH QUESTIONS}

This paper aims to contribute to the auditing literature, using the UAE as a research context. Because MAR in the UAE is still in its infancy, our contribution is through an exploratory study of the perceived association between various forms of AR and AQ in the UAE. Therefore, in this paper we address the following general question: How do UAE auditors perceive the association between various forms of $A R$ and $A Q$ ? To answer this question, we develop specific exploratory research questions presented in the following subsections.

\subsection{Perceived audit quality}

Researchers define and measure AQ in numerous ways (e.g., Azizkhani et al., 2018; Azizkhani, Monroe, and Shailer, 2013; DeAngelo, 1981; Jackson, Moldrich, and Roebuck, 2008). AQ measures are based on whether AQ is 'actual' or 'perceived' (Azizkhani et al., 2013; Daniels and Booker, 2011; Jackson et al., 2008). Measures based on actual AQ shows the extent to which an auditor reduces the risk of material errors in financial statements. Measures based on perceived AQ indicates the level of financial statement users' confidence in the auditor's effectiveness at reducing material misstatement in financial statements (Jackson et al., 2008). Examples of perceived AQ proxies include users' level of confidence in the quality of audited financial statements (Gates, Jordan Lowe, and Reckers, 2006) and users' perception of AI (Daniels and Booker, 2011). Others are earnings response coefficient as a proxy for investor perception of AQ (Cameran et al., 2016; Daugherty, Dickins, Hatfield, and Higgs, 2012; Hohenfels, 2016) and investors' perceptions as proxied by the ex-ante cost of equity capital (Azizkhani et al., 2013). Arguably, it seems, perceived AQ is a popular AQ measurement perspective in experimental and survey research. 
The various AQ definitions indicate the difficulties in measuring AQ. Indeed, any AQ proxy measure would not be perfect for two main reasons. First, quality is a user- and context-relative concept. Auditors, auditees, financial statement users and regulators may have different expectations of and incentives for AQ. Thus, they may emphasize different aspects of the AQ construct. Consequently, there is no general consensus among researchers on how to define or measure AQ (Iskandar, Rahmat, and Ismail, 2010; Kilgore, 2007) because it is a multidimensional latent construct (Tepalagul and Lin, 2015). Second, in most cases the source of data for AQ proxies is only the publicly available information. While privately held information by auditors and auditees may provide a more objective and accurate measure of $\mathrm{AQ}$, this information is very rarely accessible to researchers due to the confidential nature of audit-related activities and information. Thus, for our paper, we managed to negotiate access to a sample of auditors who agreed to respond to our questionnaire and give their perceptions of the association between various forms of AR and AQ in the UAE.

\subsection{Audit rotation enforceability and perceived audit quality}

AR could be mandatory (enforceable) or voluntary (non-enforceable). Mandatory auditor rotation (MAR) is defined as the imposition of a limit on the period of years during which an audit firm or partner can be the auditor of a company (ADAA, 2014; UAE, 2015; USA, 2002). MAR is a form of regulatory intervention into quality control processes of audit firms, and believed to address potential threats to AI caused by long tenure auditor-client association (Daugherty et al., 2012; IESBA, 2016; USA, 2002). In contrast, a voluntary audit rotation (VAR) is one in which a change of auditor is not imposed by any laws, standards or regulations. In situations where MAR has not been introduced, the auditing profession frequently cites VAR as one way of protecting auditors from potential reputational threat caused by compromised AI due to long auditor-client relationship (IESBA, 2016). In addition, the existence of market and economic incentives reinforces the motivation for VAR (DeAngelo, 1981; DeFond and Francis, 2005). Considerable research has examined the association between these two forms of $\mathrm{AR}$ and $\mathrm{AQ}$, and found mixed results (Cameran, Merlotti, and Di Vincenzo, 2005; Cameran et al., 2016; Chi, Huang, Liao, and Xie, 2009; Ebimobowei and Keretu, 2011; Gates et al., 2006).

Proponents of MAR argue that imposing AR improves AQ by forcing a reduction in audit clients' influence over auditors or auditor complacency (Daugherty et al., 2012; Turner, 2002). There are studies which support this position. For example, Ebimobowei and Keretu 
(2011) find a positive relationship between MAR and AI and the quality of audit reports. In a MAR setting, where audit firms are appointed for a three-year period and their term can be renewed twice up to a maximum of nine years, Cameran et al. (2016) find that the auditor becomes more conservative in the last year of the three-year period (i.e. years preceding the MAR). This suggests that MAR could help audit firms to take a more independent position and improve $\mathrm{AQ}$.

Opponents of MAR, however, argue that substandard audits occur more frequently for newer clients because auditors have less information/knowledge about these firms (Johnson et al., 2002; Stanley and DeZoort, 2007). In addition, newly appointed audit firms are mostly concerned with recovering start-up costs, and can easily be influenced by the audit client during early years of an audit engagement (Geiger and Raghunandan, 2002; Ruiz-Barbadillo, Gómez-Aguilar, and Biedma-López, 2006). Consistently, Kwon, Lim, and Simnett (2011) findings suggest that while audit firm and audit client costs increased upon adoption of MAR, there was no statistically significant positive effect on AQ.

A systematic review of regulators and academic studies by Cameran et al. (2005) finds that the benefits of MAR are largely unconfirmed. For example, while MAR appeared to be positively associated with auditors' 'independence in appearance' (i.e. 'perceived AI'), most empirical non-perception studies find that MAR is negatively associated with auditors' 'independence in fact' (Cameran et al., 2005). Another developing perspective is that MAR may not be necessary if audit committees periodically consider whether the current auditor is providing the highest quality services available, and advise the management when a change of auditor is necessary (CAQ, 2015). CAQ (2015) view on MAR and its contingent effect on AQ is consistent with that of Bowlin et al. (2015) who find that the beneficial effects of MAR on AQ are achieved only when the auditors' assessment of the management representation is based on the framework that the management is honesty, rather than when the auditors hold a skeptical mindset. In a recent study of the relation between pre-MAR and AQ in Iran, Azizkhani et al. (2018) find that frequent AR appeared to improve the financial reporting quality. However, due to deficiencies in AQ inherent in the Iranian audit market, the authors were careful not to interpret their findings as supporting MAR policy in Iran.

As indicated in the background information in Section 2, AR is not new in the UAE because some audit firms have been practicing VAR. However, after some debates and consultations on the merits and demerits of VAR and MAR (Grant Thornton, 2015; The CFO, 2015; Venkataraman, 2018), the UAE government decided that the status quo (i.e. continuing to rely on VAR only) was not desirable, and that introducing MAR will further 
improve AQ. Thus, MAR was recently introduced in the UAE (ADAA, 2014; UAE, 2015). To the best of our knowledge, no study has empirically investigated whether AR enforceability is associated with AQ in the UAE context. Therefore, we explore the perceptions of UAE auditors on whether the AR-AQ association differs depending on AR enforceability (i.e. MAR or VAR). Accordingly, we state the first exploratory research question (ERQ-1) as follows:

ERQ-1: Do UAE auditors perceive the MAR-AQ association as being significantly different from the VAR-AQ association?

We further explore the perceptions of the importance of AR in improving AQ. Specifically, we explore the level of agreement/disagreement among UAE auditors on whether AR is essential in improving AQ, enhances the success of auditor efforts, and increases trust in the outcome of the audit process. In this regard, we pose our second ERQ as follows:

ERQ-2: To what extent do UAE auditors agree, disagree, or remain indifferent (neutral) on whether $A R$ is (a) essential in improving $A Q,(b)$ enhances the success of auditor efforts and decreases audit failures, and (c) increases trust in the outcome of the audit process?

\subsection{Audit tenure and perceived audit quality}

Audit tenure (AT) can be defined as the length of a continuous relationship between an audit firm and a client (Johnson et al., 2002). Johnson et al. (2002) classify AT into three categories: short audit tenure (SAT) (2-3 years), medium audit tenure (MAT) (4-8 years), and long audit tenure (LAT) (9 or more years). Many studies have examined the association between audit tenure (AT) and AQ, and found mixed results (Abedalqader Al-Thuneibat, Tawfiq Ibrahim Al Issa, and Ata Baker, 2011; Azizkhani et al., 2013; Brooks, 2011; Davis et al., 2009; Johnson et al., 2002; Myers et al., 2003; Stanley and DeZoort, 2007).

Myers et al. (2003) argue that new auditors tend to rely more heavily on management estimates and representation in the initial years of an audit engagement, which may increase the likelihood of producing poor AQ. Specifically, Myers et al. (2003) investigate the relation between AT and earnings quality measured by discretionary and current accruals. They find that the magnitude of both types of accrual declines (implying better earnings 
quality, hence AQ) with LAT. They also find that LAT is negatively associated with both extreme income-increasing and income-decreasing accruals, which suggests that extreme and potentially opportunistic earnings management becomes more limited as AT gets longer. Overall, they find no evidence that a LAT is associated with lower earnings quality, which may imply that the longer the AT the better the AQ. Jackson et al. (2008) support this finding in an Australian setting when they find that AQ increased with LAT.

In contrast to studies which find periodic AR do not improve AQ, Copley and Doucet (1993) find that the probability of producing poor AQ increases with the length of the auditor-client relationship. Vanstraelen (2000) finds that renewable LAT significantly increases the likelihood of a clean audit opinion or significantly reduces the auditor's willingness to qualify audit reports. The study finds this association to be more pronounced in the last year than in the first two years of the renewable AT. This indicates that guaranteed renewable LAT may lead to impairment of AI and reduced AQ towards the end of the AT. This finding is supported by Ouyang and Wan (2013) who find that LAT (particularly longer than 10 years) affects AQ negatively, but this effect only exists in small firms, which is consistent with findings in Azizkhani et al. (2013) and Abedalqader Al-Thuneibat et al. (2011). According to Abedalqader Al-Thuneibat et al. (2011), LAT leads to deterioration in AQ due to two main reasons. First, LAT increases the satisfaction with and confidence of the audit client in the audit team, and vice versa. This may lead into compromises between the auditor and the audit client and reduce the level of auditor skepticism essential for an effective audit. Second, in a LAT situation, the audit firm could consider the audit client as a permanent income/annuity source, which may compromise the AI. A practical implication of this finding is to support a MAR policy.

Brooks (2011) investigates the impact of the 'bonding effect' and the 'learning effect' on the AT-AQ relationship. The literature suggests that the bonding effect impairs the AI, which implies that LAT leads to poor AQ (Daugherty et al., 2012). On the contrary, the learning effect impacts the AT-AQ relationship in a positive way because in a LAT the auditor becomes more knowledgeable of the audit-client's operations, procedures and systems, and becomes less dependent on management estimates and representations (Daugherty et al., 2012). Brooks (2011) argues that the net impact of these two potentially opposing forces determines whether AQ is a concave, convex or linear function of AT. Brooks (2011) findings are supported by Johnson et al. (2002), and a more recent study by Azizkhani et al. (2013). Azizkhani et al. (2013) find a non-linear association between AT and perceived AQ, to the extent that perceived AQ improves with AT for several years, and 
declines depending on the size of audit firm involved (significantly for smaller audit firms, but not for the big audit firms such as the Big 4). Moreover, Azizkhani et al. (2013) find the turning point to be longer than the three-year MAR and four-year MAR required at the UAE federal level (The CFO, 2015; UAE, 2015) and at the Abu Dhabi governance level (ADAA, 2014), respectively.

Arguably, therefore, the inverted-U (non-linear) AT-AQ association (Azizkhani et al., 2013; Brooks, 2011) appears to help in reconciling the seemingly conflicting findings of studies that find either negative or positive AT-AQ relationship (Copley and Doucet, 1993; Davis et al., 2009; Myers et al., 2003; Vanstraelen, 2000). Consequently, the perceived ATAI/AQ association would be expected to differ depending on the AT length. Accordingly, we state our third ERQ as follows:

ERQ-3: Do UAE auditors' perceptions of the association between AT and AI impairment significantly differ depending on the AT length (i.e. SAT, MAT and LAT)?

\subsection{Forms of audit rotation, demographic differences and perceived audit quality}

In addition to AR enforceability (VAR/MAR) and length of AT (SAT/MAT/LAT), AR could be at a firm, team or individual/partner level. Studies are also not conclusive on whether AR level has a negative or positive effect on AQ (Garcia-Blandon and Argiles-Bosch, 2017; Gates et al., 2006). For example, in an experimental study, results reveal that even in an environment of strong corporate governance controls, AR at firm level incrementally influenced individuals' confidence in financial statements, but AR at partner level did not have a similar effect (Gates et al., 2006). Garcia-Blandon and Argiles-Bosch (2017) find that without considering the interaction effects, the separate $\mathrm{AR}$ of a firm and a partner are not significant as determinants of AQ. Indeed, the interaction of AR at firm and partner levels indicates stronger effects on AQ than both levels of AR separately considered. Thus, we argue that the various forms of AR will have an association with AQ and we explore UAE auditors' perceptions of this association. This leads us to state our fourth ERQ as follows:

ERQ-4: To what extent do UAE auditors agree or disagree that forms of AR (i.e. enforceability, tenure, and level) are associated with AQ? 
Finally, as part of our exploratory investigation, we aim to explore the differences in perceptions based on the demographics of the respondents and participating audit firms. Hence, we pose our fifth ERQ as follows:

\section{ERQ-5: To what extent are respondents' perceptions different because of demographic variables?}

\section{RESEARCH METHODS}

The overall research environment in the Arab Middle East countries has improved in recent years, but it is still a big challenge to conduct large-scale empirical research on organizations and companies in these countries because of the difficulties in gaining access to data (Zahra, 2011). According to Zahra (2011, p. 19) "personal contacts and connections matter a great deal in gaining access to data from Arab Middle East companies." We agree with Zahra (2011) observation, because that was the experience in the current study. In 2014, using personal contacts and connections of one of the authors, we gained access to a sample of 144 audit firms operating in the UAE, and managed to recruit a sample of respondents from these firms.

\subsection{Sampling and data collection}

Using the personal contacts and connections of one of the authors, we managed to get access to 144 (20\% of 720 ) audit firms in the UAE, which agreed to participate in data collection using a questionnaire. At the time of data collection and writing the first draft of this paper (2016/17), the UAE had 720 such firms (Everington, 2015). The sampled audit firms included the Big 4 (PwC, Deloitte, Ernst \& Young and KPMG). We contacted respondents by obtaining the telephone numbers and email addresses of the audit firms from publicly available directories and firm websites, with the help of two research assistants and staff of the audit firms who agreed to participate in the study.

The questionnaire was distributed to 144 audit firms in October 2015, and the last questionnaire was collected in January 2016. The questionnaire collected the perceptions of the respondents on the association between various forms of AR and AQ (Appendix 4), and the perceived importance of AR and its association with auditor efforts, audit failure and trust in the audit process (Appendix 3). We also collected the demographics of respondents (Appendix 1) and the participating audit firms (Appendix 2). Before administering the 
questionnaire, we pilot tested it with 10 respondents. We managed to collect 144 questionnaires, but we excluded 11 questionnaires from the analysis because of incompleteness or missing responses to some key questions. Thus, we had 133 valid questionnaires for data analysis.

\subsection{Data analysis}

With the limited knowledge of the AR phenomenon in the UAE (Grant Thornton, 2015), the study sought to explore respondents' perceptions of the associations between various forms of AR and AQ. To answer the ERQs 1-5 developed in Section 3, we applied a range of statistical techniques to test the significance of respondents' perceptions of several variables about the AR-AQ association. Table 2 summarizes the link between the ERQs, the questionnaire statements used to collect the perceptions, and the statistical techniques applied to address the ERQs.

Table 2: ERQ and Statistical Techniques Applied

\begin{tabular}{|c|c|}
\hline ERQ and related Questionnaire Statements & Statistical technique applied \\
\hline $\begin{array}{l}\text { Five-point Likert-style rating scale - Respondents rated how } \\
\text { strong they agreed or disagreed that MAR and VAR are associated } \\
\text { with AQ: } \\
\text { ERQ-1: Questionnaire Statements Q19 and Q20 (Appendix 4). }\end{array}$ & $\begin{array}{l}\text { - Related-Samples Wilcoxon } \\
\text { Signed-Rank Test. }\end{array}$ \\
\hline $\begin{array}{l}\text { Five-point Likert-style rating scale converted into dichotomous } \\
\text { scores - Respondents agreed or disagreed/remained neutral on a } \\
\text { range of AR-AQ association statements: } \\
\text { ERQ-2: Questionnaire Statements Q11, Q13*, Q18 (Appendix 3). } \\
\text { ERQ-4: Questionnaire Statement Q17 (Appendix 4). }\end{array}$ & - Binomial Test. \\
\hline $\begin{array}{l}\text { Five-point Likert-style rating scale - Respondents rated how } \\
\text { strong they agreed or disagreed that SAT, MAT and LAT are } \\
\text { associated with AQ: } \\
\text { ERQ-3: Questionnaire Statements Q14, Q15, and Q16 (Appendix 4). }\end{array}$ & $\begin{array}{l}\text { - Related-Samples Friedman's } \\
\text { Two-Way ANOVA by Ranks } \\
\text { Test [initial analysis] } \\
\text { - Related-Samples Wilcoxon } \\
\text { Signed-Rank Test [follow-up } \\
\text { analysis] }\end{array}$ \\
\hline $\begin{array}{l}\text { Used the relevant Likert-style rating scale to explore the } \\
\text { differences in perceptions by demographic variables: } \\
\text { ERQ-5: Are the respondents' perceptions significantly different } \\
\text { based on the demographic variables? }\end{array}$ & $\begin{array}{l}\text { - Kruskal Wallis Test [initial } \\
\text { analysis] } \\
\text { - Mann-Whitney U-Test } \\
\text { [follow-up analysis] }\end{array}$ \\
\hline
\end{tabular}


In order to conduct the Binomial Tests to answer ERQs 2 and 4, the questionnaire responses to statements 11 (AR is essential for AQ improvement), 13 (AR decreases auditor efforts and increases audit failure), 17 (forms of $A R$ are associated with $A Q$ ), and 18 (AR increases trust in the outcome of audit process) were transformed into dichotomous scores. The transformed scores were "one" if the respondent rated 'Strongly Agree' or 'Agree' and "zero" otherwise. We employed the SPSS software (Field, 2016, 2018) to analyze the data for descriptive and other statistical information.

\section{RESULTS AND DISCUSSION}

\subsection{Demographics of respondents and participating audit firms}

Appendices 1-4 present the demographic data and descriptive analysis of the respondents and participating audit firms, and respondents' perceptions of the exploratory statements. Appendix 1a shows that the sample contained more male $(56.4 \%)$ than female $(43.6 \%)$ respondents. In terms of age of respondents as presented in Appendix 1b, there is only one age group with more female (60.6\%) than male (39.4\%), which is the 31-40 years age group. The results also show that $56.0 \%$ of males are in the youngest age group (18-30 years) while this is $46.6 \%$ for females. However, if we combine the two younger age groups (18-40 years) and the two older age groups (41-60 years), Appendix $1 \mathrm{~b}$ shows that $81.1 \%$ of females are in the younger age group compared to $73.3 \%$ of males. Overall, our sample comprises of younger $(76.7 \%)$ than older $(23.3 \%)$ respondents.

The main differences in men versus women are in terms of academic (Appendix 1c) and professional (Appendix 1d) qualifications. There is a reasonable indication that most respondents possess some form of higher academic (60.2\%) and/or professional (45.1\%) education. This indicates high levels of academic and professional awareness on issues related to $\mathrm{AR}$ and $\mathrm{AQ}$, and the potential to enhance the credibility of their responses to our questionnaire. Except for respondents with PhDs (more females, 73.3\% than males, 26.7\%), among those holding BSc and MSc qualifications there are more males $(70.7 \%, 66.7 \%)$ than females $(29.3 \%, 33.3 \%)$, respectively. The "Other" academic and professional qualifications account for $39.8 \%$ and $54.9 \%$ of respondents, respectively. However, very few respondents indicated what the "Other" qualifications were. For those few respondents, the "Other" academic qualifications included B.Com, BBA, MBA and M.Com, and the "Other" professional qualifications included the Institute of Internal Auditors (IIA) certificate, Certified Financial Services Auditor (CFSA), Certified Internal Auditor (CIA) and Chartered 
Financial Analyst (CFA). Appendices 1c and 1d show that among females, 46.6\% (males $34.7 \%$ ) and $70.7 \%$ (42.7\%) held the "Other" academic and/or professional qualifications, respectively.

In terms of accounting and/or audit professional work experience (PWE), more than two-thirds (66.9\%) of the respondents have six or more years of experience (Appendix 1e). Thus, potentially, they have reasonable awareness of the role that AR could or could not play in improving $\mathrm{AQ}$. We believe this enhances the validity of the questionnaire responses. In addition, Appendix 1e does not indicate any clearly discernible patterns of differences in the sample distribution either within the PWE groups or within gender. One thing to take note of, however, is that the PWE of $64 \%$ of males ( $65.5 \%$ of females) ranged between less than 5 to 10 years, and for $25.3 \%$ of males (29.3\% of females), PWE ranged from 11 to 15 years.

Apart from the Senior Manager position (10.5\% of respondents), the other positions (Manager, Senior Associate, Trainee, and "Other") are almost evenly distributed, ranging from about $19.5 \%$ (Senior Associate) to $27.1 \%$ (Manager) of the respondents. In addition, like the PWE, the sample distribution in terms of respondents' position in the audit firm (PAF) do not indicate significant differences either within PAF groups or within gender. However, we can highlight that except for the "Other" PAF (51.7\% females and $48.3 \%$ males) there are more males than females in the other four PAF groups. The trainee group has the highest difference between males (67.9\%) and females (32.1\%). The "Other" PAF group contains $21.8 \%$ of respondents but like in the "Other" academic and professional qualifications, very few respondents indicated what the "Other" PAF represented. For those few who indicated it, the "Other" PAF groups included Junior Audit Associate, Audit Assistant, Audit Consultant and Internal Audit Manager/controller.

The data and descriptive statistics on participating audit firms' demographics (Appendix 2) show that most (83\%) of the audit clients operate in Service (36\%), Manufacturing (28\%) and Trading (19\%) industry. Sixteen per cent (16\%) of the participating audit firms are self-employed with sponsorship, $15 \%$ are directly or indirectly owned by the UAE government, $25 \%$ are registered under the consulting category, and $44 \%$ are under the other categories such as partnership audit firms and corporate bodies like the Big 4 audit firms. The size of the participating audit firms in terms of turnover and number of employees appears to have similar frequency distribution. We applied Cronbach's Alpha to test the reliability (internal consistency) of the responses to the 10 exploratory statements 11 - 20 (Appendices 3 and 4). The reliability test indicates that the responses have the 
acceptable degree of internal consistency. The Cronbach's Alpha is 0.793, which is within the generally accepted limit of 0.70 or higher (Field, 2016, 2018; Kline, 2013).

\subsection{AR enforceability and perceived $A Q$}

ERQ-1 asks whether UAE auditors perceive the MAR-AQ association and VAR-AQ association differently. To answer this question, we employed the Related-Samples Wilcoxon Signed-Rank Test to test the differences between Q19 responses and Q20 responses. Table 3 shows the test result as $\mathrm{T}=1,627.50, \mathrm{p}=0.115$ (2-sided). This indicates that at the 0.05 level of significance, we are not able to reject the null hypothesis that there is no significant difference in the respondents' perception of the MAR-AQ association, and that between VAR and AQ.

Table 3: Related-Samples Wilcoxon Signed Test - ERQ-1 [Q19 v/s Q20]

\begin{tabular}{l|c|c|c}
\hline Null Hypothesis & N & T-test & $\begin{array}{c}\text { Asymp. Sig. } \\
\text { (2-sided)* }\end{array}$ \\
\hline $\begin{array}{l}\text { The median of differences between Q19. MAR is associated } \\
\text { with AQ and Q20. VAR is associated with AQ equals 0. }\end{array}$ & 133 & $1,627.50$ & 0.115 \\
\hline Positive differences^ $^{\wedge}$ & 42 & & \\
\hline Negative differences & 31 & & \\
Number of ties & 60 & & \\
Total & $\mathbf{1 3 3}$ & & \\
\hline$*$ The significance level is 0.05. & & \\
$\wedge$ Q20 scores minus Q19 scores. &
\end{tabular}

The results in Table 3 suggest that MAR and VAR are perceived as having similar association with AQ. In other words, it matters very little whether AR is enforceable (mandatory) or unenforceable (voluntary). If there is any AR-AQ association, then it will more likely be similar for both forms of AR. This appears to be consistent with the results for ERQ-4 (discussed later). However, while the results are insignificant, Table 3 also shows that there are more positive differences $(\mathrm{N}=42)$ than negative differences $(\mathrm{N}=31)$. This is indicative of more respondents in agreement with the statement 'MAR is associated with AQ' than with the statement "VAR is associated with AQ' . Arguably, though insignificant, this could partly explain the recent increase in support for MAR in the UAE.

ERQ-2 further explores the perceptions of the importance of AR in improving AQ. The question asks the extent to which UAE auditors agree, disagree, or remain indifferent (neutral) on whether AR is (a) essential in improving AQ, (b) enhances auditor efforts and decreases audit failures, and (c) increases trust in the outcome of the audit process. To answer

\footnotetext{
${ }^{1}$ Note that the statement scores were such that the lowest score (1) was "Strongly Agree" and the highest score (5) was "Strongly Disagree".
} 
this question, we employed several Binomial Tests to test the extent of respondents' agreement or disagreement on whether the potential qualitative aspects of AR as mentioned in ERQ-2 are associated with AQ. Table 4 summarizes the statistical results.

Table 4: Binomial Tests for ERQ-2

\begin{tabular}{l|l|c|c|c|c}
\hline ERQ statement & Category & N & $\begin{array}{c}\text { Observed } \\
\text { Prop. }\end{array}$ & $\begin{array}{c}\text { Test } \\
\text { Prop. }\end{array}$ & $\begin{array}{c}\text { Exact Sig. } \\
\text { (2-tailed)* }\end{array}$ \\
\hline $\begin{array}{c}\text { (a) AR is essential for audit firms to } \\
\text { improve AQ [Q11] }\end{array}$ & Agree & 123 & 0.92 & 0.50 & 0.000 \\
& Disagree/Neutral & 10 & 0.08 & & \\
\cline { 2 - 7 } & Total & 133 & 1.00 & & \\
\hline \multirow{2}{*}{$\begin{array}{c}\text { (b) AR enhances auditor efforts \& } \\
\text { decreases audit failure [Q13]** }\end{array}$} & Agree & 31 & 0.23 & 0.50 & 0.000 \\
\cline { 2 - 7 } & Disagree/Neutral & 102 & 0.77 & & \\
\cline { 2 - 7 } & Total & 133 & 1.00 & & \\
\hline \multirow{2}{*}{$\begin{array}{c}\text { AR increases trust in the outcome } \\
\text { of the audit process [Q18] }\end{array}$} & Agree & 80 & 0.60 & 0.50 & 0.024 \\
\cline { 2 - 6 } & Disagree/Neutral & 53 & 0.40 & & \\
\cline { 2 - 6 } & Total & 133 & 1.00 & & \\
\hline
\end{tabular}

*All tests are significant at the 0.05 level.

** As indicated in Appendix 3, respondents' scores and the statement for this question are reversed to be consistent with the other statements.

Regarding ERQ-2(a), Table 4 indicates that the proportion of respondents agreeing that AR is essential for audit firms to improve AQ of 0.92 is significantly higher than the expected $0.50, \mathrm{p}=.000$ (2-sided). This result suggests that UAE auditors generally view AR as an essential/important element of measures taken to improve AQ. This perception of UAE auditors is consistent with the views from, and recent actions of the UAE government, which seem to recognize the significance of $A R$ in improving $A Q$, and decided to enforce $A R$ by imposing MAR (The CFO, 2015; UAE, 2015). This view is based on the belief that AR helps auditors not to lose their independence and/or become less skeptical (Daugherty et al., 2012; Ebimobowei and Keretu, 2011; Turner, 2002).

On ERQ-2(b), Table 4 indicates that the proportion of respondents agreeing that AR enhances auditor efforts and decreases audit failures of 0.23 is significantly lower than the expected $0.50, \mathrm{p}=.000$ (2-sided). This result appears to suggest that most auditors in the UAE perceive AR as negatively affecting audit efforts and that it is likely to increase audit failures/quality. This seems to contradict the perception that AR is essential for AQ improvement as supported by the results of ERQ-2(a) above. However, it is possible that respondents viewed AR as essential in a broader rather than in a specific sense as suggested by ERQ-2(b). That is, respondents did not perceive AR on its own as a sufficient mechanism for specifically improving auditor efforts and reducing audit failures. The apparent 
contradiction in perceptions noted here is arguably similar to one of the findings in the paper by Daugherty et al. (2012). Daugherty et al. (2012) found that while their respondents generally agreed that AR "improves independence in both fact and appearance", and that it "reduces inappropriate auditor-client attachment", the same respondents perceived "little or no value resulting from accelerated rotation or extended cooling-off period" (p. 106).

ERQ-2(c) aimed to explore the respondents' perceptions of the issue of AR and its association with trust in the outcome of the audit process. Table 4 indicates that the proportion of respondents agreeing that AR increases trust in the outcome of the audit process of 0.60 is significantly higher than the expected $0.50, p=.024$ (2-sided). This shows more support for the view (among respondents), than not, that the audit process can be trusted more in improving the quality of financial accounting information if audit firms practice AR. This result is consistent with the results of ERQ-2(a).

Interestingly, however, while the results for ERQ-2(a) indicate that UAE auditors perceived AR as essential in improving AQ, about half of them were either neutral or disagreed that $A R$ is voluntarily practiced in the UAE (Appendix 3, Q12). This indicates unawareness that VAR is practiced in the UAE. This is inconsistent with the background information discussed in Section 2, which shows that AR is not new in the UAE because some audit firms have been practicing VAR. Two factors could explain this apparent inconsistency. First, it is possible that these respondents had not experienced or heard about VAR being practiced in their current or previous employment. Second, respondents' awareness of VAR being practiced in the UAE may positively correlate with their professional work experience or official position (Appendix 1, Q6 and Q7, respectively). Given the data available to us, we are not able to determine precisely which factor, or factors, explain this inconsistency. However, we conducted a Spearman's correlation analysis between the responses to Q12, and those of Q6 and Q7, and the results do not significantly help to explain why about $50 \%$ of respondents were not aware or not very sure that VAR is practiced in the UAE. The results show that the correlation between responses to Q12 and Q6 is insignificant non-strong negative $\left[\mathrm{r}_{\mathrm{s}}=-0.105, \mathrm{n}=133, \mathrm{p}<.231\right]$ and that with $\mathrm{Q} 7$ is significant non-strong positive $\left[\mathrm{r}_{\mathrm{s}}=0.321, \mathrm{n}=133, \mathrm{p}<.001\right]^{2}$. More evidence of how this inconsistency can be explained is in Section 5.4.

While we cannot establish the reason for this observed lack of awareness by half of our respondents, these same respondents did agree that $\mathrm{AR}$ is an essential/important element in

\footnotetext{
${ }^{2}$ In Section 5.4, more evidence of how this inconsistency can be explained is presented in the discussion of the results of testing the differences in perceptions by gender (Table 8).
} 
AQ improvement. Indeed, we can arguably conclude that this finding is to some extent consistent with the support for MAR in the UAE.

\subsection{Length of $A T$ and perceived $A Q$}

ERQ-3 asks whether UAE auditors' perception of the association between AT and AI impairment significantly differs depending on the length of AT (i.e. SAT, MAT and LAT). To answer this question, we first employed the Related-Samples Friedman's Two-Way ANOVA by Ranks Test to test whether there are significant differences in the responses to Q14, Q15 and Q16. Table 5 shows the test result as $\chi^{2}(2)=6.563, p=0.038$. This indicates that, at the 0.05 level of significance, we can reject the null hypothesis that the distributions of respondents' perceptions of the association between length of AT and AI impairment are not statistically different. Consequently, the initial results suggest that the answer to ERQ-3 is that UAE auditors differently perceive the association between various lengths of AT and AI impairment.

Table 5: Related-Samples Friedman's Two-Way ANOVA by Ranks Test - ERQ-3 [Q14, Q15 and Q16]

\begin{tabular}{l|c|c|c|c|c}
\hline Null Hypothesis & N & $\begin{array}{c}\text { Mean } \\
\text { Rank }\end{array}$ & $\begin{array}{c}\text { Chi- } \\
\text { Square }\end{array}$ & df & $\begin{array}{c}\text { Asymp. Sig. } \\
\text { (2-sided)* }\end{array}$ \\
\hline $\begin{array}{l}\text { The distributions of Q14, Q15 and Q16 scores are not } \\
\text { significantly different from each other. }\end{array}$ & 133 & & 6.563 & 2 & 0.038 \\
\hline Q14. SAT impairs AI and decreases AQ & & 1.91 & & & \\
\hline Q15. MAT impairs AI and decreases AQ & & 2.14 & & & \\
\hline Q16. LAT impairs AI and decreases AQ & & 1.95 & & & \\
\hline *The significance level is 0.05.
\end{tabular}

Table 5 shows that the mean ranking of 2.14 for Q15 - "MAT impairs AI and decreases $A Q$ ” - is higher than for the other statements, 1.91 for Q14 and 1.95 for Q16. This suggests that most respondents disagreed with this statement compared to the other statements. This implies that SAT and LAT are perceived to be more likely to impair AI and decrease AQ than MAT. Arguably, this result is consistent with studies which find that very short or long AT do not improve AQ. Further, this finding appears to support a non-linear inverted-U relationship between length of AT and AQ (Azizkhani et al., 2013; Brooks, 2011; Johnson et al., 2002). However, Table 5 does not tell us the pairwise comparison of how respondents perceived the association between various lengths of AT and AI. For example, is SAT perceived better than MAT and LAT, or is MAT perceived better than LAT when it comes to AI and AQ? Therefore, we conducted a follow-up analysis using the Related-Samples Wilcoxon Signed-Rank Test (Field, 2016, 2018), and present the results in the following discussion of Table 6. 
Table 6: Related-Samples Wilcoxon Signed Test -ERQ-3 follow-up pairwise tests

\begin{tabular}{l|c|c|c}
\hline & A & B & C \\
\hline Score pairs Tested & Q14 $\boldsymbol{v} \mathbf{s} \mathbf{Q 1 5}$ & $\mathbf{Q 1 4} \boldsymbol{v / s} \mathbf{Q 1 6}$ & $\mathbf{Q 1 5} \boldsymbol{v / s} \mathbf{Q 1 6}$ \\
\hline $\begin{array}{l}\text { Null Hypothesis: The median of } \\
\text { differences between ... and ... equals 0 } \\
\text { (zero) }\end{array}$ & Q14 and Q15 & Q14 and Q16 & Q15 and Q16 \\
\hline T-test & $1,899.00$ & $1,770.50$ & $1,266.00$ \\
\hline Asymp. Sig. (2-sided)* & 0.001 & 0.736 & 0.022 \\
\hline Positive differences^ & 47 & 43 & 33 \\
\hline Negative differences & 26 & 39 & 50 \\
\hline Number of ties & 60 & 51 & 50 \\
\hline *Level of significance & 0.05 & 0.05 & 0.05 \\
\hline$\wedge$ Score differences computed as & Q15 minus Q14 & Q16 minus Q14 & Q16 minus Q15 \\
\hline Total N & $\mathbf{1 3 3}$ & $\mathbf{1 3 3}$ & $\mathbf{1 3 3}$ \\
\hline Q14. SAT impairs AI and decreases AQ & & & \\
\hline Q15. MAT impairs AI and decreases AQ & & & \\
\hline Q16. LAT impairs AI and decreases AQ & & & \\
\hline
\end{tabular}

First, Table 6-Column A presents results comparing perceptions of the association between SAT and AI impairment and decrease in AQ, and the association between MAT and AI impairment and decrease in AQ. The results show $\mathrm{T}=1,899.00, \mathrm{p}=0.001$ (2-sided). This indicates that, at the 0.05 level of significance, the null hypothesis is rejected. Therefore, there is a statistically significant difference in the way respondents perceived Q14 - "SAT impairs AI and decreases AQ" and Q15 - "MAT impairs AI and decreases $A Q "$ " The results in Table 6 show the direction of the differences in perceptions with more positive $(\mathrm{N}=47)$ than negative $(\mathrm{N}=26)$ differences. This is indicative that more respondents agree that "SAT impairs $A I$ and decreases $A Q$ " than those who agree that "MAT impairs AI and decreases $A Q$ ". This is consistent with the interpretation that MAT is perceived to have lower impairment effect on AI compared to SAT. This provides further support for our interpretation of the results in Table 5 .

Second, Table 6-Column B presents results comparing perceptions of the association between SAT and AI impairment and decrease in AQ, and between LAT and AI impairment and decrease in AQ. The results show that $\mathrm{T}=1,770.50, \mathrm{p}=0.736$ (2-sided). This indicates that, at the 0.05 level of significance, the null hypothesis could not be rejected. Therefore, there is no statistically significant difference in the way respondents scored statements Q14 and Q16.

Statistically, the results in Table 7 suggest that we do not have enough evidence to conclude that perceptions of respondents on SAT-AI impairment and LAT-AI impairment 
associations are different. In other words, it does not matter whether AT is short or long; if there is any association between length of AT and AI impairment, then it is more likely that the association will be similar for both AT lengths. Notably, however, the direction of the differences (more positives, $\mathrm{N}=43$, than negatives, $\mathrm{N}=39$ ) suggests that if the results were significant, the LAT would have lower impairment effect on AI compared to SAT.

Third, the MAT-LAT pairwise comparison is presented in Table 6-Column C. The results show that $\mathrm{T}=1,266.00, \mathrm{p}=0.022$ (2-sided). This indicates that, at the 0.05 level of significance, the null hypothesis is rejected. Therefore, there is a significant difference between the responses to Q15 - "MAT impairs AI and decreases in AQ" and Q16 - "LAT impairs $A I$ and decreases $A Q$ ". The results in Table 6 also show the direction of the differences in perceptions with less positive $(\mathrm{N}=33)$ than negative $(\mathrm{N}=50)$ differences. This indicates that more respondents in our sample agree that "LAT impairs AI and decreases AQ" than those who agree that "MAT impairs AI and decreases $A Q$ ". This is consistent and supports the results and interpretation of Table 5 and the SAT-MAT pairwise comparison results above.

Based on the significant results discussed above, we conclude that the answer to ERQ-3 is divided into two parts. First, the UAE auditors in our sample perceived the association between various lengths of AT (i.e. SAT, MAT and LAT) and AI impairment/AQ differently. Second, it appears that more respondents perceived SAT and LAT to impair AI and decrease AQ compared to MAT. This means that MAT is perceived to have lower impairment effect on AI/AQ compared to SAT and LAT. This result does not allow us to conclude that MAT improves AI/AQ. However, we can arguably suggest that this result supports the perception that very short or long AT is unfavorable to AI/AQ, and is consistent with the inverted-U (non-linear) relationship between AT and AQ (Azizkhani et al., 2013; Brooks, 2011; Johnson et al., 2002).

\subsection{Forms of AR, demographic differences and $A Q$}

We employed a Binomial Test to test the extent of respondents' agreement or disagreement on whether forms of AR are associated with AQ (ERQ-4). Table 7 summarizes the statistical results to answer these questions. For ERQ-4, Table 7 shows that the proportion of respondents agreeing that forms of AR are associated with AQ of 0.56 is not significantly higher than the expected $0.50, \mathrm{p}=.165$ (2-sided). This result suggests that, overall, the respondents' perception of the general association between various forms of AR and AQ is equally divided and there is no decisive view either way. This seems to be consistent with the results on ERQ-1. 
Table 7: Binomial Tests for ERQ-4

\begin{tabular}{l|l|c|c|c|c}
\hline Exploratory Research Question & Category & N & $\begin{array}{c}\text { Observed } \\
\text { Prop. }\end{array}$ & $\begin{array}{c}\text { Test } \\
\text { Prop. }\end{array}$ & $\begin{array}{c}\text { Exact Sig. } \\
\text { (2-tailed)* }\end{array}$ \\
\hline \multirow{2}{*}{$\begin{array}{l}\text { ERQ-4: Forms of AR are associated } \\
\text { with AQ [Q17] }\end{array}$} & Agree & 75 & 0.56 & 0.50 & 0.165 \\
\cline { 2 - 6 } & Disagree/Neutral & 58 & 0.44 & & \\
\cline { 2 - 6 } & Total & 133 & 1.00 & & \\
\hline
\end{tabular}

*All tests are significant at the 0.05 level.

We then conducted an analysis of the differences in perceptions by demographic variables. In ERQ-5 we asked, To what extent are respondents' perceptions different because of demographic variables? We performed Mann-Whitney U-test and Kruskal Wallis Test (as is appropriate) to explore this question. We analyzed whether there are significant differences in perceptions based on respondents' gender, professional work experience, type of audit practice, and audit firm size categories.

Table 8: Differences in perceptions by GENDER

\begin{tabular}{lc|c|c|c|c}
\hline \multicolumn{7}{c}{$\begin{array}{c}\text { Q11. AR is } \\
\text { essential for } \\
\text { AQ improve. }\end{array}$} & $\begin{array}{c}\text { Q12. VAR is } \\
\text { practiced in } \\
\text { the UAE }\end{array}$ & $\begin{array}{c}\text { Q13r. AR Decr. } \\
\text { auditor efforts and } \\
\text { incr. audit failure }\end{array}$ & $\begin{array}{c}\text { Q14. SAT } \\
\text { impairs AI and } \\
\text { decr. AQ }\end{array}$ & $\begin{array}{c}\text { Q15. MAT } \\
\text { impairs AI and } \\
\text { decr. AQ }\end{array}$ \\
\hline Mann-Whitney U & 2019.000 & 1611.500 & 2025.000 & 1885.000 & 1881.500 \\
\hline Wilcoxon W & 4869.000 & 3322.500 & 4875.000 & 3596.000 & 4731.500 \\
\hline Z & -.805 & -2.698 & -.703 & -1.408 & -1.384 \\
\hline $\begin{array}{l}\text { Asymp. Sig. (2- } \\
\text { tailed) }\end{array}$ & .421 & $\mathbf{. 0 0 7}$ & .482 & .159 & .167 \\
\hline
\end{tabular}

a. Grouping Variable: Q1. Gender

Table 8 (contd.):

\begin{tabular}{lc|c|c|c|c}
\hline & $\begin{array}{c}\text { Q16. LAT } \\
\text { impairs AI and } \\
\text { decr. AQ }\end{array}$ & $\begin{array}{c}\text { Q17. Forms of } \\
\text { AR are assoc. } \\
\text { with AQ }\end{array}$ & $\begin{array}{c}\text { Q18. AR incr. trust } \\
\text { in the outcome of } \\
\text { audit process }\end{array}$ & $\begin{array}{c}\text { Q19. MAR is } \\
\text { assoc. with } \\
\text { AQ }\end{array}$ & $\begin{array}{c}\text { Q20. VAR is } \\
\text { assoc. with AQ }\end{array}$ \\
\hline Mann-Whitney U & 1967.500 & 1844.000 & 1820.000 & 2170.500 & 2099.500 \\
\hline Wilcoxon W & 4817.500 & 4694.000 & 4670.000 & 5020.500 & 3810.500 \\
\hline Z & -.973 & -1.580 & -1.683 & -.021 & -.354 \\
\hline $\begin{array}{l}\text { Asymp. Sig. (2- } \\
\text { tailed) }\end{array}$ & .331 & .114 & .092 & .983 & .724 \\
\hline
\end{tabular}

a. Grouping Variable: Q1. Gender

In terms of differences in perceptions based on respondents' gender, Table 8 indicates that all the test results, except for $\mathrm{Q} 12-$ "VAR is practiced in the UAE”, are insignificant. The test result for Q12 are $U=1611.5, Z=-2.698, p=007$ (two-tailed). This shows that at the 0.05 level of significance, male respondents disagreed more than female respondents that VAR is practiced in the UAE (see Appendix 5 for the test mean ranks). This result provides additional statistical evidence that helps to explain the apparent inconsistency between the background information which shows VAR is not new in the UAE (Section 2) and the seeming lack of this awareness by 
about half of respondents (see the last three paragraphs of Section 5.2). This result can explain two things. First, more males than females in our sample were not aware that some UAE firms have been practicing VAR. Second, our sample contained more female than male respondents from VAR-practicing audit firms, thus increasing the possibility of these women being aware of VAR practices in the UAE.

The differences in perceptions between the five categories of experience in years is shown in Table 9. The Kruskal-Wallis test shows significant differences of perceptions between the years of experience categories for all the questions except for Q12-"VAR is practiced in the UAE” (Table 9a). Table 9b shows the follow-up test using the Mann-Whitney U-test to determine which pairs of professional experience categories contribute significantly to the differences in perceptions.

Table 9: Differences in respondents' perceptions by professional work EXPERIENCE

Table 9a: Overall perception differences of categories of professional work EXPERIENCE in years

\begin{tabular}{|c|c|c|c|c|c|c|c|}
\hline \multicolumn{8}{|c|}{ Test Statistics $^{\mathrm{a}, \mathrm{b}}$} \\
\hline & $\begin{array}{l}\text { Q19. MAR } \\
\text { is assoc. } \\
\text { with AQ }\end{array}$ & $\begin{array}{l}\text { Q20. VAR } \\
\text { is assoc. } \\
\text { with AQ }\end{array}$ & $\begin{array}{l}\text { Q11. AR is } \\
\text { essential for } \\
\text { AQ improve. }\end{array}$ & $\begin{array}{l}\text { Q12. VAR is } \\
\text { practiced in } \\
\text { the UAE }\end{array}$ & $\begin{array}{c}\text { Q14. SAT } \\
\text { impairs AI and } \\
\text { decr. AQ }\end{array}$ & $\begin{array}{l}\text { Q15. MAT } \\
\text { impairs AI and } \\
\text { decr. AQ }\end{array}$ & $\begin{array}{l}\text { Q16. LAT } \\
\text { impairs AI and } \\
\text { decr. AQ }\end{array}$ \\
\hline Chi-Square & 19.035 & 26.225 & 7.951 & 3.648 & 13.959 & 22.377 & 20.322 \\
\hline df & 4 & 4 & 4 & 4 & 4 & 4 & 4 \\
\hline Asymp. Sig. ${ }^{c}$ & $.001 * * *$ & $.000 * * *$ & $.093 \dagger$ & .456 & $.007 * * *$ & $.000 * * *$ & $.000 * * *$ \\
\hline $\begin{array}{l}\text { a. Kruskal Wal } \\
\text { b. Grouping V } \\
\text { c. Level of sigl }\end{array}$ & $\begin{array}{l}\text { Test } \\
\text { able: Q6. } \\
\text { cance: }\end{array}$ & $\begin{array}{l}\text { t/Accou } \\
100, * p\end{array}$ & $\begin{array}{l}\text { ion } \\
\leq 0\end{array}$ & erie & Years & & \\
\hline
\end{tabular}

Table 9b: Specific perception differences between categories of professional EXPERIENCE in years

\begin{tabular}{|c|c|c|c|c|c|c|}
\hline \multicolumn{7}{|c|}{ Test Statistics ${ }^{\mathbf{a}}$} \\
\hline \multicolumn{2}{|c|}{$\begin{array}{c}\text { Experience- } \\
\text { Years Categories } \\
\text { Compare }\end{array}$} & $\begin{array}{l}\text { Q19. MAR } \\
\text { is assoc. } \\
\text { with AQ }\end{array}$ & $\begin{array}{l}\text { Q20. VAR } \\
\text { is assoc. } \\
\text { with AQ }\end{array}$ & $\begin{array}{c}\text { Q14. SAT } \\
\text { impairs AI } \\
\text { and decr. AQ }\end{array}$ & $\begin{array}{l}\text { Q15. MAT } \\
\text { impairs AI } \\
\text { and decr. AQ }\end{array}$ & $\begin{array}{l}\text { Q16. LAT } \\
\text { impairs AI and } \\
\text { decr. AQ }\end{array}$ \\
\hline \multirow{2}{*}{$\begin{array}{l}<\mathbf{5} \text { v/s 6-10 } \\
\text { years Exp. }\end{array}$} & Mann-Whitney U & 521.000 & 394.000 & 764.000 & 596.000 & 523.000 \\
\hline & Asymp. Sig. b, c & $.000 * * *$ & $.000 * * *$ & .132 & $.002 *$ & $.000 * * *$ \\
\hline \multirow{2}{*}{$\begin{array}{l}<5 \text { v/s 11-15 } \\
\text { years Exp. }\end{array}$} & Mann-Whitney U & 432.500 & 383.500 & 465.000 & 380.000 & 445.500 \\
\hline & Asymp. Sig. & $.000 * * *$ & $.000 * * *$ & $.001 * *$ & $.000 * * *$ & $.000 * * *$ \\
\hline \multirow{2}{*}{$\begin{array}{l}<5 \text { v/s } \mathbf{1 6 - 2 0} \\
\text { years Exp. }\end{array}$} & Mann-Whitney U & 118.500 & 113.500 & 128.500 & 81.000 & 68.500 \\
\hline & Asymp. Sig. & .301 & .233 & .452 & .031 & .013 \\
\hline \multirow{2}{*}{$\begin{array}{l}<\mathbf{5} \text { v/s } \mathbf{2 1 +} \\
\text { years Exp. }\end{array}$} & Mann-Whitney U & 48.000 & 60.500 & 40.000 & 16.000 & 22.000 \\
\hline & Asymp. Sig. & .113 & .267 & .054 & $.004 *$ & $.009 \dagger$ \\
\hline
\end{tabular}

a. Grouping Variable: Q6. Audit/Accounting professional work experience-Years

b. Bonferroni correction to adjust p-value and avoid inflated Type I error rate because of testing multiple hypotheses using same data is given by critical p-value $(\alpha)$ /number of tests (Field, 2016, 2018). For example, for a critical p-value of 0.05 and 10 tests (e.g. 10 group comparisons or hypothesis tests), the adjusted p-value is given by $=0.05 / 10=0.005$. Therefore, the adjusted level of significance (critical p-values) for this test are: $\uparrow \mathrm{p} \leq 0.0100,{ }^{*} \mathrm{p} \leq 0.0050, * * \mathrm{p} \leq 0.0010, * * * \mathrm{p} \leq 0.0005$.

c. Two-tailed test.

d. For brevity, we have included the significant pair-wise comparisons only.

Table $9 \mathrm{~b}$ indicates that the respondents with less than 5 years of experience compared to those with 6-10 and 11-15 years of experience show significant differences in perceptions in all 
questions (except for Q14 - "SAT impairs AI and decreases AQ”). The results show that the less professionally experienced respondents agreed more (than the more professionally experienced respondents) that AR enforceability (Q19 and Q20), and the AT length (Q14, Q15, and Q16) are associated with AQ. Arguably, we can infer that the increasing support to introduce MAR in recent years in the UAE may have been significantly driven or influenced by the younger generation of accounting/auditing professionals. This interpretation is consistent with Daugherty et al. (2012), who found that experienced audit partners perceived "little to no value resulting from accelerated MAR or extended cooling off periods" (p. 106).

We also tested the differences in perception between respondents by type of audit practice in which respondents worked. The results for this test are shown in Table 10. The Kruskal-Wallis test shows significant differences of perceptions for all the questions except for Q11- "AR being essential for $A Q$ improvement (Table 10a). Table 10b shows the follow-up test using the MannWhitney U-test to determine which pairs of types of audit practice contribute significantly to the differences in perceptions.

Table 10: Differences in respondents' perceptions by type of PRACTICE

Table 10a: Overall differences in perceptions by type of PRACTICE

\begin{tabular}{|c|c|c|c|c|c|c|c|}
\hline \multicolumn{8}{|c|}{ Test Statistics ${ }^{\mathrm{a}, \mathrm{b}}$} \\
\hline & $\begin{array}{c}\text { Q19. MAR } \\
\text { is assoc. } \\
\text { with AQ }\end{array}$ & $\begin{array}{l}\text { Q20. VAR } \\
\text { is assoc. } \\
\text { with AQ }\end{array}$ & $\begin{array}{l}\text { Q11. AR is } \\
\text { essential for } \\
\text { AQ improve. }\end{array}$ & $\begin{array}{l}\text { Q12. VAR is } \\
\text { practiced in } \\
\text { the UAE }\end{array}$ & $\begin{array}{c}\text { Q14. SAT } \\
\text { impairs AI } \\
\text { and decr. AQ }\end{array}$ & $\begin{array}{c}\text { Q15. MAT } \\
\text { impairs AI } \\
\text { and decr. AQ }\end{array}$ & $\begin{array}{l}\text { Q16. LAT impairs AI } \\
\text { and decr. AQ }\end{array}$ \\
\hline Chi-Square & 23.446 & 12.905 & 5.925 & 13.377 & 11.200 & 19.519 & 25.649 \\
\hline df & 3 & 3 & 3 & 3 & 3 & 3 & 3 \\
\hline Asymp. Sig. ${ }^{c}$ & $.000 * * *$ & $.005 * * *$ & .115 & $.004 * * *$ & $.011 *$ & $.000 * * *$ & $.000 * * *$ \\
\hline $\begin{array}{l}\text { a. Kruskal W } \\
\text { b. Grouping } \\
\text { c. Level of si }\end{array}$ & $\begin{array}{l}\text { Test } \\
\text { iable: Q } \\
\text { icance: }\end{array}$ & 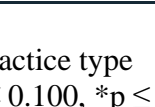 & & 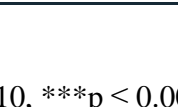 & & & \\
\hline
\end{tabular}

Table 10b: Specific differences in perceptions between two types of PRACTICES

\begin{tabular}{|c|c|c|c|c|c|c|c|}
\hline \multicolumn{8}{|c|}{ Test Statistics $^{\mathbf{a}}$} \\
\hline $\begin{array}{l}\text { Practice Types } \\
\text { Compare }\end{array}$ & & $\begin{array}{l}\text { Q19. MAR } \\
\text { is assoc. } \\
\text { with AQ }\end{array}$ & $\begin{array}{l}\text { Q20. VAR } \\
\text { is assoc. } \\
\text { with AQ }\end{array}$ & $\begin{array}{l}\text { Q12. VAR is } \\
\text { practiced in } \\
\text { the UAE }\end{array}$ & $\begin{array}{c}\text { Q14. SAT } \\
\text { impairs AI } \\
\text { and decr. AQ }\end{array}$ & $\begin{array}{c}\text { Q15. MAT } \\
\text { impairs AI } \\
\text { and decr. AQ }\end{array}$ & $\begin{array}{c}\text { Q16. LAT } \\
\text { impairs AI } \\
\text { and decr. AQ }\end{array}$ \\
\hline \multirow{2}{*}{$\begin{array}{l}\text { Self-Employed } \\
v / s \text { Government }\end{array}$} & Mann-Whitney U & 180.000 & 192.000 & 156.500 & 106.500 & 146.000 & 58.500 \\
\hline & Asymp. Sig. b, c & .403 & .619 & .138 & $.004 *$ & .066 & $.000 * * *$ \\
\hline \multirow{2}{*}{$\begin{array}{l}\text { Self-Employed } \\
v / s \text { Consulting }\end{array}$} & Mann-Whitney U & 137.000 & 156.000 & 170.500 & 205.000 & 144.000 & 92.000 \\
\hline & Asymp. Sig. & $.000 * * *$ & $.000 * * *$ & $.001 * *$ & $.005^{*}$ & $.000 * * *$ & $.000 * * *$ \\
\hline \multirow{2}{*}{$\begin{array}{l}\text { Government } v / s \\
\text { Consulting }\end{array}$} & Mann-Whitney U & 150.000 & 213.000 & 230.000 & 317.000 & 187.500 & 303.000 \\
\hline & Asymp. Sig. & $.000 * * *$ & .019 & .036 & .660 & $.005 *$ & .487 \\
\hline \multirow{2}{*}{$\begin{array}{l}\text { Consulting } v / s \\
\text { Others }\end{array}$} & Mann-Whitney U & 564.000 & 764.000 & 748.500 & 889.000 & 717.500 & 738.000 \\
\hline & Asymp. Sig. & $.000 * * *$ & .064 & .042 & .398 & .025 & .038 \\
\hline
\end{tabular}

a. Grouping Variable: Q5. Type of practice

b. Bonferroni correction to adjust p-value and avoid inflated Type I error rate because of testing multiple hypotheses using same data is given by critical p-value $(\alpha)$ /number of tests (Field, 2016, 2018). For example, for a critical p-value of 0.05 and 6 tests (e.g. 6 group comparisons or hypothesis tests), the adjusted p-value is given by $0.05 / 6=0.008$. Therefore, the adjusted level of significance (critical p-values) for this test are: $\uparrow \mathrm{p} \leq 0.0170$,

$* \mathrm{p} \leq 0.0080, * * \mathrm{p} \leq 0.0017, * * * \mathrm{p} \leq 0.0008$.

c. Two-tailed test.

d. For brevity, we have included the significant pair-wise comparisons only. 
Table 10b indicates that the respondents working in Self-Employed compared to those working in Consulting practices show significant and consistent differences in perceptions for all the questions. Table $12 \mathrm{~b}$ also shows other significant differences between practice types (e.g., Government v/s Consulting for Q19 and Q15), but they are not consistent for all the questions. The results indicate that the respondents in Self-Employed practices agreed more (than respondents in Consulting practices) that AR enforceability (Q19 and Q20), VAR is practiced in the UAE (Q12), and AT length (Q14, Q15, and Q16) are associated with AQ. Overall, this shows respondents in Self-Employed practices are more likely to support MAR than respondents in consulting practices are.

Finally, we tested the differences in perceptions between respondents by audit firm size (in turnover). The results for this test are shown in Table 11. Table 11a shows significant differences of perceptions for all the questions except for Q11- "AR being essential for $A Q$ improvement" and Q16 - "LAT impairs AI and decreases AQ". Table 11b shows the followup test to determine the pairs of firm-size categories that contribute significantly to the differences in perceptions.

Table 11: Differences in respondents' perceptions by FIRM SIZE-Turnover categories Table 11a: Overall differences in perceptions by FIRM SIZE categories

\begin{tabular}{|c|c|c|c|c|c|c|c|}
\hline \multicolumn{8}{|c|}{ Test Statistics ${ }^{\text {a,b }}$} \\
\hline & $\begin{array}{l}\text { Q19. MAR } \\
\text { is assoc. } \\
\text { with AQ }\end{array}$ & $\begin{array}{l}\text { Q20. VAR } \\
\text { is assoc. } \\
\text { with AQ }\end{array}$ & $\begin{array}{l}\text { Q11. AR is } \\
\text { essential for } \\
\text { AQ improve. }\end{array}$ & $\begin{array}{l}\text { Q12. VAR is } \\
\text { practiced in } \\
\text { the UAE }\end{array}$ & $\begin{array}{l}\text { Q14. SAT } \\
\text { impairs AI } \\
\text { and decr. AQ }\end{array}$ & $\begin{array}{l}\text { Q15. MAT } \\
\text { impairs AI } \\
\text { and decr. AQ }\end{array}$ & $\begin{array}{l}\text { Q16. LAT impairs } \\
\text { AI and decr. AQ }\end{array}$ \\
\hline Chi-Square & 10.405 & 11.010 & 1.756 & 33.150 & 11.384 & 7.515 & 3.754 \\
\hline df & 2 & 2 & 2 & 2 & 2 & 2 & 2 \\
\hline Asymp. Sig. ${ }^{c}$ & $.006 * *$ & $.004 * * *$ & .416 & $.000 * * *$ & $.003 * * *$ & $.023 *$ & .153 \\
\hline \multicolumn{8}{|c|}{$\begin{array}{l}\text { a. Kruskal Wallis Test } \\
\text { b. Grouping Variable: Q8. Audit firm size - Turnover (fees) } \\
\text { c. Level of significance: } \dagger \mathrm{p} \leq 0.100, * \mathrm{p} \leq 0.050, * * \mathrm{p} \leq 0.010, * * * \mathrm{p} \leq 0.005 \text {. }\end{array}$} \\
\hline
\end{tabular}

Table 11b: Specific differences in perceptions by between two FIRM SIZE categories

\begin{tabular}{|c|c|c|c|c|c|c|}
\hline \multicolumn{7}{|c|}{ Test Statistics ${ }^{\mathbf{a}}$} \\
\hline $\begin{array}{c}\text { Firm Size } \\
\text { Categories } \\
\text { Compare } \\
\end{array}$ & & $\begin{array}{l}\text { Q19. MAR } \\
\text { is assoc. } \\
\text { with AQ } \\
\end{array}$ & $\begin{array}{l}\text { Q20. VAR } \\
\text { is assoc. } \\
\text { with AQ } \\
\end{array}$ & $\begin{array}{l}\text { Q12. VAR is } \\
\text { practiced in } \\
\text { the UAE }\end{array}$ & $\begin{array}{c}\text { Q14. SAT } \\
\text { impairs AI } \\
\text { and decr. AQ }\end{array}$ & $\begin{array}{c}\text { Q15. MAT } \\
\text { impairs AI and } \\
\text { decr. AQ }\end{array}$ \\
\hline \multirow{2}{*}{$\begin{array}{l}<\text { AED } 1 \text { Mill } v / s \\
\text { AED 1-25 Mill }\end{array}$} & Mann-Whitney U & 780.000 & 754.000 & 533.000 & 813.000 & 856.000 \\
\hline & Asymp. Sig. ${ }^{\mathbf{b}, \mathbf{c}}$ & $.002 * * *$ & $.001 * * *$ & $.000 * * *$ & $.003 * *$ & $.011 *$ \\
\hline \multirow{2}{*}{$\begin{array}{l}<\text { AED } 1 \text { Mill } v / s \\
>\text { AED } 25 \text { Mill }\end{array}$} & Mann-Whitney U & 765.500 & 704.500 & 319.000 & 524.000 & 587.500 \\
\hline & Asymp. Sig. & .694 & .320 & $.000 * * *$ & $.004 *$ & $.032 \dagger$ \\
\hline \multirow{2}{*}{$\begin{array}{l}\text { AED 1-25 Mill } v / s \\
>\text { AED } 25 \text { Mill }\end{array}$} & Mann-Whitney U & 657.500 & 687.000 & 851.500 & 876.000 & 901.500 \\
\hline & Asymp. Sig. & $.024 \dagger$ & .045 & .575 & .752 & .939 \\
\hline
\end{tabular}

a. Grouping Variable: Q8. Audit firm size - Turnover (fees)

b. Bonferroni correction to adjust p-value and avoid inflated Type I error rate because of testing multiple hypotheses using same data is given by critical p-value $(\alpha)$ /number of tests (Field, 2016, 2018). For example, for a critical p-value of 0.05 and 3 tests (e.g. 3 group comparisons or hypothesis tests), the adjusted p-value is given by $0.05 / 3=0.0167$. Therefore, the adjusted level of significance (critical $\mathrm{p}$-values) for this test are: $\uparrow \mathrm{p} \leq 0.0333,{ }^{*} \mathrm{p} \leq 0.0167, * * \mathrm{p} \leq 0.0033, * * * \mathrm{p} \leq 0.0017$.

c. Two-tailed test. 
The results in Table $11 \mathrm{~b}$ indicate that respondents in small audit firms (turnover of below AED 1 million) compared to those in medium audit firms (turnover from AED 1 to AED 25 million) show significant and consistent differences in perceptions for all the questions. In addition, small audit firms compared to large audit firms (turnover more than AED 25 million) show significant differences in perceptions for three out of the five questions (i.e. Q12, Q14 and Q15). The other comparison (i.e. medium v/s large audit firm) shows significant difference on one question only (i.e. Q19). Overall, it appears that respondents in small audit firms agreed more than respondents in medium audit firms that AR enforceability (Q19 and Q20) and AT length (Q14, Q15 only) are associated with AQ. Therefore, we can argue that our results indicate that UAE auditors in small audit firms are more likely to support MAR than auditors in medium or large audit firms are.

\subsection{Discussions of Results}

The results of the exploratory analysis presented in Sections $5.2-5.4$ suggest, with few exceptions, that overall AR is perceived to be an important element in the efforts to enhance AQ in the UAE. Interestingly, however, while the background information (Section 2) shows that VAR is not new in the UAE, about half of respondents were not aware (or not very sure) about this fact (Section 5.2). In addition, it is males who showed more lack of awareness than females (Section 5.4). Nevertheless, these respondents significantly perceived that AR was essential for AQ improvement. We therefore argue that this could partly explain the growing support for MAR in the UAE. This finding is consistent with some of the previous studies (e.g., Chi et al., 2009; Daugherty et al., 2012; Ebimobowei and Keretu, 2011; Gates et al., 2006), but unsurprisingly appears to contradict some of the results in other studies (e.g., Ewelt-Knauer et al., 2013; Geiger and Raghunandan, 2002; Ruiz-Barbadillo et al., 2006). Arguments against audit reforms such as the introduction of MAR include the difficulties in clearly associating AR with AQ improvement, increase in transaction costs, and loss of client-specific knowledge held by an out-going audit firm (Cameran et al., 2015; Daugherty et al., 2012).

In terms of the association between AT length and AQ, we find significant support for the perception that SAT and LAT are more likely to impair AI and decrease AQ than MAT. This finding is somewhat consistent with studies that find the association between AT length and AQ as being non-linear, with inverted-U shape relationship where shorter AT (e.g., 1-3 years) and longer AT (e.g., 9 or more years) are associated with low AQ (Azizkhani et al., 2013; Brooks, 2011; Johnson et al., 2002). In addition, this finding contributes to the literature that attempts to 
resolve the mixed findings of studies that support the positive (Jackson et al., 2008; Myers et al., 2003) or the negative (Abedalqader Al-Thuneibat et al., 2011; Copley and Doucet, 1993; Davis et al., 2009; Ouyang and Wan, 2013; Vanstraelen, 2000) AT-AQ association. The current legal AT in the UAE is three years for entities required to comply with the federal law (UAE, 2015), and four years for entities required to comply with the Abu Dhabi authority law/regulation (ADAA, 2014). Based on the AT classification by Johnson et al. (2002) of MAT being 4-8 years, we argue that the AT required by the UAE laws is on the borderline; this is fairly consistent with and supported by our findings that UAE auditors agree more often than not that MAT does not impair AI or decrease AQ.

Further, while respondents were equally divided on their agreement or disagreement/neutral perceptions of whether "various forms of AR are associated with $A Q$ ", it was quite evident that they significantly agreed that "AR is essential for audit firms to improve $A Q$ ". In addition, when specifically asked whether "AR decreases auditor efforts and increases audit failure", respondents appeared to agree more than disagree that this is the case. This result seems contradictory to respondents' agreement that " $A R$ is essential to $A Q$ improvement" and that "AR increases trust in the audit process". Somewhat similar contradictory perceptions have been found in other studies. For example, in the paper by Daugherty et al. (2012), while respondents perceived that AR improves AI, they also did not perceive accelerated AR and extended cooling-off periods as adding anything to AQ.

Finally, we explored the question of whether respondents' perceptions significantly differed based on certain demographics of the respondents and participating audit firms. The demographics included in the analysis are gender, experience, type of audit firm practice and audit firm size. Overall, the gender variable did not appear to be a significant perception differentiating factor. Male and female responses to all statements were not significantly different from each other except for one (i.e. Q12). Females indicated more awareness of VAR being practiced in the UAE than their male counterparts did. In terms of professional work experience, it is the less experienced respondents who agreed more with the view that AR enforceability and AT length are associated with AQ. Similarly, based on the type of audit firm practice, it was the respondents from Self-employed practices compared to Consulting practices and small audit firms compared to medium and large audit firms who perceived AR enforceability and AT length are associated with AQ. Consequently, we suggest that, arguably, the recent rise in the support for MAR in the UAE is significantly driven or influenced by younger/less experienced professionals, and professionals employed in self-employed practices and small audit firms. 


\section{SUMMARY AND CONCLUSION}

The purpose of this study is to explore the perceived association between various forms of $\mathrm{AR}$ and AQ. Consequently, we asked this general research question: How do UAE auditors perceive the association between various forms of $A R$ and $A Q$ ? To achieve this objective, we distributed questionnaire to 144 respondents working in audit firms in the UAE and managed to collect 133 completed questionnaires with valid responses for analysis. Based on the extant literature on the AR-AQ association and the recent development in the UAE AR regulatory framework, we developed and statistically analyzed five exploratory research questions.

The study concludes that the UAE auditors in our sample did not perceive significant differences between the VAR-AQ and MAR-AQ associations. Furthermore, the apparent lack of awareness among some respondents that VAR is practiced in the UAE, combined with the respondents' significant perception that AR is essential for AQ improvement could partly explain the recent support for MAR in the UAE. We find that the perceived support for MAR is also consistent with the respondents' perceptions of the questions related to the association between the length of AT and AQ. The findings show more support for the perception that MAT is significantly associated with a lower impairment effect on AI compared to SAT and LAT. Indeed, without MAR, MAT would not be guaranteed. It is also worth noting that the perception that MAT is associated a lower impairment effect on AI appears to be consistent with the recent audit regulatory changes, which introduced a MAR of three years (federal law) and four years (Abu Dhabi authority) in the UAE (ADAA, 2014; UAE, 2015).

Further, in a rather contradictory finding, most respondents perceived AR as negatively affecting audit efforts and that it is likely to increase audit failures, but at the same time AR was perceived to increase trust in the outcome of the audit process, and as an essential element in improving AQ. This could partly be explained by the possibility that respondents could have distinguished between the importance of AR in enhancing AI (positive perception of AR) and the potential effect on the auditors' quality of life because of accelerated AR and longer cooling-off periods (negative perception of AR) as found by Daugherty et al. (2012).

In exploring whether demographics made a difference in respondents' perceptions, we found the following: there are no significant differences in perceptions, based on gender, that less experienced/younger professionals and professionals in self-employed practices and in small size audit firms (compared to other demographics) significantly perceived that enforceability of AR and AT length are associated with AQ. Specifically, the perceptions supported MAR (i.e. enforceable AR) and MAT (i.e. medium length AT) to be good for AQ. 
Our study makes important contributions to AR and AQ scholarship, particularly in the area of study. Our findings shed light on the prominent auditing debate that has been topical whether MAR increases or decreases AQ - by considering related variables and skepticism. Within the finance/accounting profession and the financial media, there has been relatively limited knowledge and a dearth of empirical studies on this question in most developing economies (Adeyemi and Okpala, 2011; Ebimobowei and Keretu, 2011; Firth et al., 2012). We show the importance of understanding the perception that MAT is associated with a lower impairment effect on AI, hence a possibility of a positive association with AQ than with SAT and LAT. We enrich our understanding of the perceived AR-AQ association in a relatively new context and less researched audit area in a developing economy.

In sum, our study provides some insights on the perceptions regarding the association between various forms of AR, AT and AQ in the area of study. While we cannot generalize the findings of the current study because they are only exploratory and specific to the UAE, we do contend that they provide some research propositions that could be further investigated in future research.

\section{Limitations and suggestions for future research}

As with many research studies, there are some limitations to this study that point to other opportunities for future research. It is possible that several idiosyncrasies within the research setting might influence the study's results. For example, we explored only some aspects of the real-world audit setting. Other factors such as audit firm switching costs, auditor expertise, and client complexity could affect the relative costs and benefits of MAR. Future research could consider such factors. Additionally, we analyze the perceptions of external auditors, which is by no means representative of all stakeholders with an interest in AQ (e.g., regulators, audit clients, and users of audited financial statements). Future research could address this by examining the perceptions of these stakeholders. Additionally, MAR is a very recent phenomenon in the UAE, and it would be interesting after five or more years of MAR implementation to investigate the effect of MAR on AQ in the UAE. This could help to evaluate whether auditors' perceptions of the effect of MAR on AQ have changed after acquiring more experience with MAR. 


\section{Appendices 1-5}

Appendix 1: Demographic variables of respondents by gender

\begin{tabular}{|c|c|c|c|c|c|c|c|c|c|c|c|}
\hline \multirow{2}{*}{\multicolumn{2}{|c|}{ Appendix 1a: }} & \multirow{2}{*}{\multicolumn{2}{|c|}{ Q1. Gender }} & \multirow{2}{*}{$\begin{array}{c}\text { Male }(\mathbf{M}) \\
75 \\
\end{array}$} & \multirow{2}{*}{$\begin{array}{l}\% \text { of } \mathbf{N} \\
56.4 \% \\
\end{array}$} & \multirow{2}{*}{\multicolumn{2}{|c|}{$\begin{array}{c}\text { Female }(\mathbf{F}) \\
58 \\
\end{array}$}} & $\%$ of $\mathbf{N}$ & \multirow{2}{*}{\multicolumn{2}{|c|}{$\begin{array}{c}\text { Total N } \\
133\end{array}$}} & $\%$ of $\mathrm{N}$ \\
\hline & & & & & & & & $43.6 \%$ & & & $100 \%$ \\
\hline \multicolumn{2}{|c|}{ Appendix 1b: } & $\begin{array}{l}\text { Q2. } \\
\text { Q1. }\end{array}$ & $\begin{array}{l}* \\
\text { der } \mathrm{Cr}\end{array}$ & sstabulati & & \multicolumn{6}{|c|}{$\begin{array}{l}\text { Q3. Academic qualification * } \\
\text { Q1. Gender Crosstabulation }\end{array}$} \\
\hline \multicolumn{3}{|c|}{$\operatorname{Age}(A)$} & \multicolumn{3}{|c|}{ Gender (G) } & \multicolumn{3}{|c|}{ Academic Qualification (AQ) } & \multicolumn{3}{|c|}{ Gender (G) } \\
\hline Years & & & $\mathbf{M}$ & $\mathbf{F}$ & Total & Deg/Cert & & & $\mathbf{M}$ & $\mathbf{F}$ & Total \\
\hline \multirow{4}{*}{$18-30$} & Count & & 42 & 27 & 69 & \multirow{4}{*}{$\begin{array}{c}\text { BSc } \\
\text { (Accounting) }\end{array}$} & \multicolumn{2}{|c|}{ Count } & 29 & 12 & 41 \\
\hline & $\%$ wit & in $\mathrm{A}$ & $60.9 \%$ & $39.1 \%$ & $100.0 \%$ & & \multicolumn{2}{|c|}{$\%$ within $\mathrm{AQ}$} & $70.7 \%$ & $29.3 \%$ & $100.0 \%$ \\
\hline & $\%$ wit & $\mathrm{G}$ & $56.0 \%$ & $46.6 \%$ & $51.9 \%$ & & \multicolumn{2}{|c|}{$\%$ within $\mathrm{G}$} & $38.7 \%$ & $20.7 \%$ & $30.8 \%$ \\
\hline & $\%$ of $^{r}$ & tal & $31.6 \%$ & $20.3 \%$ & $51.9 \%$ & & \multicolumn{2}{|c|}{$\%$ of Total } & $21.8 \%$ & $9.0 \%$ & $30.8 \%$ \\
\hline \multirow{4}{*}{$31-40$} & Count & & 13 & 20 & 33 & \multirow{4}{*}{ MSc } & \multicolumn{2}{|c|}{ Count } & 16 & 8 & 24 \\
\hline & $\%$ wit & in $\mathrm{A}$ & $39.4 \%$ & $60.6 \%$ & $100.0 \%$ & & \multicolumn{2}{|c|}{$\%$ within $\mathrm{AQ}$} & $66.7 \%$ & $33.3 \%$ & $100.0 \%$ \\
\hline & $\%$ wit & in $G$ & $17.3 \%$ & $34.5 \%$ & $24.8 \%$ & & \multicolumn{2}{|c|}{$\%$ within $\mathrm{G}$} & $21.3 \%$ & $13.8 \%$ & $18.0 \%$ \\
\hline & $\%$ of $^{r}$ & tal & $9.8 \%$ & $15.0 \%$ & $24.8 \%$ & & \multicolumn{2}{|c|}{$\%$ of Total } & $12.0 \%$ & $6.0 \%$ & $18.0 \%$ \\
\hline & Count & & 15 & 9 & 24 & & \multicolumn{2}{|c|}{ Count } & 4 & 11 & 15 \\
\hline & $\%$ wit & in $\mathrm{A}$ & $62.5 \%$ & $37.5 \%$ & $100.0 \%$ & & $\% \mathrm{n}$ & thin AQ & $26.7 \%$ & $73.3 \%$ & $100.0 \%$ \\
\hline $41-50$ & $\%$ wit & in $G$ & $20.0 \%$ & $15.5 \%$ & $18.0 \%$ & PnD & $\% \mathrm{n}$ & thin $G$ & $5.3 \%$ & $19.0 \%$ & $11.3 \%$ \\
\hline & $\%$ of & tal & $11.3 \%$ & $6.8 \%$ & $18.0 \%$ & & $\% \mathrm{o}$ & Total & $3.0 \%$ & $8.3 \%$ & $11.3 \%$ \\
\hline & Count & & 5 & 2 & 7 & & $\mathrm{Cou}$ & & 26 & 27 & 53 \\
\hline & $\%$ wit & in $\mathrm{A}$ & $71.4 \%$ & $28.6 \%$ & $100.0 \%$ & & $\% \mathrm{u}$ & thin $\mathrm{AQ}$ & $49.1 \%$ & $50.9 \%$ & $100.0 \%$ \\
\hline $51-60$ & $\%$ wit & in $G$ & $6.7 \%$ & $3.4 \%$ & $5.3 \%$ & hers & $\% \mathrm{u}$ & thin $G$ & $34.7 \%$ & $46.6 \%$ & $39.8 \%$ \\
\hline & $\%$ of & tal & $3.8 \%$ & $1.5 \%$ & $5.3 \%$ & & $\%$ o & Total & $19.5 \%$ & $20.3 \%$ & $39.8 \%$ \\
\hline
\end{tabular}

\begin{tabular}{|c|c|c|c|c|c|c|c|c|c|}
\hline \multicolumn{5}{|c|}{ Appendix 1d: } & \multicolumn{5}{|c|}{ Appendix 1e: Q1. Gender Crosstabulation } \\
\hline \multicolumn{2}{|c|}{$\begin{array}{c}\text { Professional } \\
\text { Qualification (PQ) }\end{array}$} & \multicolumn{3}{|c|}{ Gender $(\mathbf{G})$} & \multicolumn{2}{|c|}{ Prof. Work Experience (PWE) } & \multicolumn{3}{|c|}{ Gender (G) } \\
\hline Cert. & & $\mathbf{M}$ & $\mathbf{F}$ & Total & Years & & $\mathbf{M}$ & $\mathbf{F}$ & Total \\
\hline \multirow{4}{*}{$\mathrm{CA}$} & Count & 5 & 4 & 9 & \multirow{4}{*}{ Less than 5} & Count & 27 & 17 & 44 \\
\hline & $\%$ within $\mathrm{PQ}$ & $55.6 \%$ & $44.4 \%$ & $100.0 \%$ & & $\%$ within PWE & $61.4 \%$ & $38.6 \%$ & $100.0 \%$ \\
\hline & $\%$ within $\mathrm{G}$ & $6.7 \%$ & $6.9 \%$ & $6.8 \%$ & & $\%$ within $\mathrm{G}$ & $36.0 \%$ & $29.3 \%$ & $33.1 \%$ \\
\hline & $\%$ of Total & $3.8 \%$ & $3.0 \%$ & $6.8 \%$ & & $\%$ of Total & $20.3 \%$ & $12.8 \%$ & $33.1 \%$ \\
\hline \multirow{4}{*}{ ACCA } & Count & 18 & 2 & 20 & \multirow{4}{*}{$6-10$} & Count & 21 & 21 & 42 \\
\hline & $\%$ within $\mathrm{PQ}$ & $90.0 \%$ & $10.0 \%$ & $100.0 \%$ & & $\%$ within PWE & $50.0 \%$ & $50.0 \%$ & $100.0 \%$ \\
\hline & $\%$ within $\mathrm{G}$ & $24.0 \%$ & $3.4 \%$ & $15.0 \%$ & & $\%$ within $\mathrm{G}$ & $28.0 \%$ & $36.2 \%$ & $31.6 \%$ \\
\hline & $\%$ of Total & $13.5 \%$ & $1.5 \%$ & $15.0 \%$ & & $\%$ of Total & $15.8 \%$ & $15.8 \%$ & $31.6 \%$ \\
\hline \multirow{4}{*}{ CPA } & Count & 10 & 3 & 13 & \multirow{4}{*}{$11-15$} & Count & 19 & 17 & 36 \\
\hline & $\%$ within PQ & $76.9 \%$ & $23.1 \%$ & $100.0 \%$ & & $\%$ within PWE & $52.8 \%$ & $47.2 \%$ & $100.0 \%$ \\
\hline & $\%$ within $\mathrm{G}$ & $13.3 \%$ & $5.2 \%$ & $9.8 \%$ & & $\%$ within $\mathrm{G}$ & $25.3 \%$ & $29.3 \%$ & $27.1 \%$ \\
\hline & $\%$ of Total & $7.5 \%$ & $2.3 \%$ & $9.8 \%$ & & $\%$ of Total & $14.3 \%$ & $12.8 \%$ & $27.1 \%$ \\
\hline \multirow{4}{*}{$\mathrm{ACA}$} & Count & 10 & 8 & 18 & \multirow{4}{*}{$16-20$} & Count & 6 & 1 & 7 \\
\hline & $\%$ within $\mathrm{PQ}$ & $55.6 \%$ & $44.4 \%$ & $100.0 \%$ & & $\%$ within PWE & $85.7 \%$ & $14.3 \%$ & $100.0 \%$ \\
\hline & $\%$ within $\mathrm{G}$ & $13.3 \%$ & $13.8 \%$ & $13.5 \%$ & & $\%$ within $\mathrm{G}$ & $8.0 \%$ & $1.7 \%$ & $5.3 \%$ \\
\hline & $\%$ of Total & $7.5 \%$ & $6.0 \%$ & $13.5 \%$ & & $\%$ of Total & $4.5 \%$ & $0.8 \%$ & $5.3 \%$ \\
\hline
\end{tabular}




\begin{tabular}{|c|c|c|c|c|c|c|c|c|c|}
\hline \multirow{4}{*}{ Other } & Count & 32 & 41 & 73 & \multirow{4}{*}{$21+$} & Count & 2 & 2 & 4 \\
\hline & $\%$ within $\mathrm{PQ}$ & $43.8 \%$ & $56.2 \%$ & $100.0 \%$ & & $\%$ within PWE & $50.0 \%$ & $50.0 \%$ & $100.0 \%$ \\
\hline & $\%$ within $\mathrm{G}$ & $42.7 \%$ & $70.7 \%$ & $54.9 \%$ & & $\%$ within $\mathrm{G}$ & $2.7 \%$ & $3.4 \%$ & $3.0 \%$ \\
\hline & $\%$ of Total & $24.1 \%$ & $30.8 \%$ & $54.9 \%$ & & $\%$ of Total & $1.5 \%$ & $1.5 \%$ & $3.0 \%$ \\
\hline
\end{tabular}

Appendix 1f: Q7. Position in the audit firm *

Appendix 1f: Q1. Gender Crosstabulation

\begin{tabular}{|c|c|c|c|c|}
\hline \multicolumn{2}{|c|}{ Position in the Audit Firm (PAF) } & \multicolumn{3}{|c|}{ Gender (G) } \\
\hline Position & & Male & Female & Total \\
\hline \multirow{4}{*}{ Senior Manager } & Count & 8 & 6 & 14 \\
\hline & $\%$ within PAF & $57.1 \%$ & $42.9 \%$ & $100.0 \%$ \\
\hline & $\%$ within $\mathrm{G}$ & $10.7 \%$ & $10.3 \%$ & $10.5 \%$ \\
\hline & $\%$ of Total & $6.0 \%$ & $4.5 \%$ & $10.5 \%$ \\
\hline \multirow{4}{*}{ Manager } & Count & 20 & 16 & 36 \\
\hline & $\%$ within PAF & $55.6 \%$ & $44.4 \%$ & $100.0 \%$ \\
\hline & $\%$ within $\mathrm{G}$ & $26.7 \%$ & $27.6 \%$ & $27.1 \%$ \\
\hline & $\%$ of Total & $15.0 \%$ & $12.0 \%$ & $27.1 \%$ \\
\hline \multirow{4}{*}{$\begin{array}{c}\text { Senior } \\
\text { Associate }\end{array}$} & Count & 14 & 12 & 26 \\
\hline & $\%$ within PAF & $53.8 \%$ & $46.2 \%$ & $100.0 \%$ \\
\hline & $\%$ within $\mathrm{G}$ & $18.7 \%$ & $20.7 \%$ & $19.5 \%$ \\
\hline & $\%$ of Total & $10.5 \%$ & $9.0 \%$ & $19.5 \%$ \\
\hline \multirow{4}{*}{ Trainee } & Count & 19 & 9 & 28 \\
\hline & $\%$ within PAF & $67.9 \%$ & $32.1 \%$ & $100.0 \%$ \\
\hline & $\%$ within $\mathrm{G}$ & $25.3 \%$ & $15.5 \%$ & $21.1 \%$ \\
\hline & $\%$ of Total & $14.3 \%$ & $6.8 \%$ & $21.1 \%$ \\
\hline \multirow{4}{*}{ Other } & Count & 14 & 15 & 29 \\
\hline & $\%$ within PAF & $48.3 \%$ & $51.7 \%$ & $100.0 \%$ \\
\hline & $\%$ within $\mathrm{G}$ & $18.7 \%$ & $25.9 \%$ & $21.8 \%$ \\
\hline & $\%$ of Total & $10.5 \%$ & $11.3 \%$ & $21.8 \%$ \\
\hline
\end{tabular}


Appendix 2: Demographics of participating audit firms

\begin{tabular}{|c|c|c|c|}
\hline Question & Variable & $\mathrm{N}=133$ & $\%$ \\
\hline \multirow[t]{5}{*}{ Q5 } & Type of Practice/ownership: & & \\
\hline & Self Employed & 21 & 16 \\
\hline & Government & 20 & 15 \\
\hline & Consulting & 34 & 25 \\
\hline & Others & 58 & 44 \\
\hline \multirow[t]{4}{*}{ Q8 } & Firm size - Turnover: & & \\
\hline & Below AED 1 million & 46 & 35 \\
\hline & AED 1 million to AED 25 million & 52 & 39 \\
\hline & Above AED 25 million & 35 & 26 \\
\hline \multirow[t]{4}{*}{ Q9 } & Firm size - No. of employees: & & \\
\hline & Less than 50 employees & 46 & 35 \\
\hline & 50 to 100 employees & 51 & 38 \\
\hline & More than 100 employees & 36 & 27 \\
\hline \multirow[t]{5}{*}{ Q10 } & Industry of most audit clients: & & \\
\hline & Service & 48 & 36 \\
\hline & Manufacturing & 37 & 28 \\
\hline & Trading & 25 & 19 \\
\hline & Other & 23 & 17 \\
\hline
\end{tabular}

Appendix 3: Perceived association between AR and AQ

\begin{tabular}{|c|c|c|c|}
\hline Question & Statement & $\mathrm{N}=133$ & $\%$ \\
\hline \multirow[t]{4}{*}{ Q11 } & $A R$ is essential for $A Q$ improvement: & & \\
\hline & Strongly Agree & 75 & 56 \\
\hline & Agree & 48 & 36 \\
\hline & Neutral & 10 & 8 \\
\hline \multirow[t]{6}{*}{ Q12 } & $\begin{array}{l}\text { Audit rotation }(A R) \text { is voluntarily practiced in the } \\
\text { UAE: }\end{array}$ & & \\
\hline & Strongly Agree & 20 & 15 \\
\hline & Agree & 46 & 35 \\
\hline & Neutral & 51 & 38 \\
\hline & Disagree & 14 & 11 \\
\hline & Strongly Disagree & 2 & 1 \\
\hline \multirow[t]{5}{*}{ Q13 } & $\begin{array}{l}\text { AR enhances auditor efforts and decreases audit } \\
\text { failures*: }\end{array}$ & & \\
\hline & Agree & 31 & 23 \\
\hline & Neutral & 35 & 26 \\
\hline & Disagree & 33 & 25 \\
\hline & Strongly disagree & 34 & 26 \\
\hline \multirow[t]{6}{*}{ Q18 } & AR increases trust in the outcome of the audit process: & & \\
\hline & Strongly Agree & 34 & 25 \\
\hline & Agree & 46 & 35 \\
\hline & Neutral & 39 & 29 \\
\hline & Disagree & 13 & 10 \\
\hline & Strongly Disagree & 1 & 1 \\
\hline
\end{tabular}


Appendix 4: Perceived association between forms of AR and AQ

\begin{tabular}{|c|c|c|c|}
\hline Question & Statement & $\mathbf{N}=\mathbf{1 3 3}$ & $\%$ \\
\hline \multirow[t]{5}{*}{ Q14 } & $\begin{array}{l}\text { Short audit tenure (SAT) impairs audit independence (AI) and } \\
\text { decreases } A Q \text { : }\end{array}$ & & \\
\hline & Strongly Agree & 15 & 11 \\
\hline & Agree & 58 & 44 \\
\hline & Neutral & 46 & 35 \\
\hline & Disagree & 14 & 10 \\
\hline \multirow[t]{6}{*}{ Q15 } & Medium audit tenure (MAT) impairs AI and decreases AQ: & & \\
\hline & Strongly Agree & 16 & 12 \\
\hline & Agree & 47 & 36 \\
\hline & Neutral & 35 & 26 \\
\hline & Disagree & 28 & 21 \\
\hline & Strongly Disagree & 7 & 5 \\
\hline \multirow[t]{6}{*}{ Q16 } & Long audit tenure (LAT) impairs AI and decreases $A Q$ : & & \\
\hline & Strongly Agree & 31 & 23 \\
\hline & Agree & 39 & 29 \\
\hline & Neutral & 38 & 29 \\
\hline & Disagree & 15 & 11 \\
\hline & Strongly Disagree & 10 & 8 \\
\hline \multirow[t]{6}{*}{ Q17 } & Forms of $A R$ are associated with $A Q$ : & & \\
\hline & Strongly Agree & 24 & 18 \\
\hline & Agree & 51 & 38 \\
\hline & Neutral & 43 & 32 \\
\hline & Disagree & 6 & 5 \\
\hline & Strongly Disagree & 9 & 7 \\
\hline \multirow[t]{6}{*}{ Q19 } & Mandatory audit rotation (MAR) is associated with $A Q$ & & \\
\hline & Strongly Agree & 32 & 24 \\
\hline & Agree & 42 & 32 \\
\hline & Neutral & 37 & 28 \\
\hline & Disagree & 12 & 9 \\
\hline & Strongly Disagree & 10 & 7 \\
\hline \multirow[t]{6}{*}{ Q20 } & Voluntary audit rotation (VAR) is associated with $A Q$ : & & \\
\hline & Strongly Agree & 26 & 19 \\
\hline & Agree & 41 & 31 \\
\hline & Neutral & 38 & 29 \\
\hline & Disagree & 15 & 11 \\
\hline & Strongly Disagree & 13 & 10 \\
\hline
\end{tabular}


Appendix 5: Mann-Whitney Test for differences in perceptions by GENDER - Mean Ranks.

\begin{tabular}{|c|c|c|c|c|}
\hline & Q1. Gender & $\mathrm{N}$ & Mean Rank & Sum of Ranks \\
\hline \multirow{3}{*}{ Q11. AR is essential for AQ improvement } & Male & 75 & 64.92 & 4869.00 \\
\hline & Female & 58 & 69.69 & 4042.00 \\
\hline & Total & 133 & & \\
\hline \multirow{3}{*}{ Q12. AR is voluntarily practiced in the UAE } & Male & 75 & 74.51 & 5588.50 \\
\hline & Female & 58 & 57.28 & 3322.50 \\
\hline & Total & 133 & & \\
\hline \multirow{3}{*}{$\begin{array}{l}\text { Q13r. AR Decreases auditor efforts and } \\
\text { increase audit failure }\end{array}$} & Male & 75 & 65.00 & 4875.00 \\
\hline & Female & 58 & 69.59 & 4036.00 \\
\hline & Total & 133 & & \\
\hline \multirow{3}{*}{ Q14. SAT impairs AI and decreases AQ } & Male & 75 & 70.87 & 5315.00 \\
\hline & Female & 58 & 62.00 & 3596.00 \\
\hline & Total & 133 & & \\
\hline \multirow{3}{*}{ Q15. MAT impairs AI and decreases AQ } & Male & 75 & 63.09 & 4731.50 \\
\hline & Female & 58 & 72.06 & 4179.50 \\
\hline & Total & 133 & & \\
\hline \multirow{3}{*}{ Q16. LAT impairs AI and decreases AQ } & Male & 75 & 64.23 & 4817.50 \\
\hline & Female & 58 & 70.58 & 4093.50 \\
\hline & Total & 133 & & \\
\hline \multirow{3}{*}{ Q17. Forms of $\mathrm{AR}$ are associated with $\mathrm{AQ}$} & Male & 75 & 62.59 & 4694.00 \\
\hline & Female & 58 & 72.71 & 4217.00 \\
\hline & Total & 133 & & \\
\hline \multirow{3}{*}{$\begin{array}{l}\text { Q18. AR increases trust in the outcome of } \\
\text { audit process }\end{array}$} & Male & 75 & 62.27 & 4670.00 \\
\hline & Female & 58 & 73.12 & 4241.00 \\
\hline & Total & 133 & & \\
\hline \multirow{3}{*}{ Q19. MAR is associated with AQ } & Male & 75 & 66.94 & 5020.50 \\
\hline & Female & 58 & 67.08 & 3890.50 \\
\hline & Total & 133 & & \\
\hline \multirow{3}{*}{ Q20. VAR is associated with AQ } & Male & 75 & 68.01 & 5100.50 \\
\hline & Female & 58 & 65.70 & 3810.50 \\
\hline & Total & 133 & & \\
\hline
\end{tabular}




\section{References}

Abdullah, A.-M., Naser, K. and Al-Enazi, N. (2017), "An Empirical Investigation of Factors Affecting Audit Fees: Evidence from Kuwait", International Advances in Economic Research, Vol. 23 No. 3, pp. 333-347.

Abedalqader Al-Thuneibat, A., Tawfiq Ibrahim Al Issa, R. and Ata Baker, R. A. (2011), "Do audit tenure and firm size contribute to audit quality? Empirical evidence from Jordan", Managerial Auditing Journal, Vol. 26 No. 4, pp. 317-334.

ADAA. (2014), "Statutory Auditors Appointment Rules (SAAR) - 11 October 2014". Abu Dhabi Accountability Authority (ADAA), Published online on 10/11/2012. Available at: http://www.adaa.abudhabi.ae/en/mediacenter/news/Pages/SAAR2014.aspx (accessed 01/01/2018).

Adeyemi, S. B. and Okpala, O. (2011), "The impact of audit independence on financial reporting: Evidence from Nigeria", Business and Management Review, Vol. 1 No. 4, pp. 9-25.

Arel, B., Brody, R. G. and Pany, K. (2005), "Audit firm rotation and audit quality", The CPA Journal, Vol. 75 No. 1, pp. 36.

Arnold, T. (2014), "Over 1 in 4 UAE companies are victims of fraud". The National Business, Online, 26 February 2014, 04:00AM. Available at: https://www.thenational.ae/business/over-1-in-4-uae-companies-are-victims-of-fraud1.278243 (accessed 18/02/2019).

Azizkhani, M., Daghani, R. and Shailer, G. (2018), "Audit Firm Tenure and Audit Quality in a Constrained Market", The International Journal of Accounting, Vol. 53 No. 3, pp. 167-182.

Azizkhani, M., Monroe, G. S. and Shailer, G. (2013), "Audit Partner Tenure and Cost of Equity Capital", Auditing: A Journal of Practice \& Theory.

Bowlin, K. O., Hobson, J. L. and Piercey, M. D. (2015), "The effects of auditor rotation, professional skepticism, and interactions with managers on audit quality", The Accounting Review, Vol. 90 No. 4, pp. 1363-1393.

Brooks, L. Z. (2011), "Auditor tenure and audit quality", Department of Accounting, Louisiana State University and Agricultural and Mechanical College.

Cameran, M., Merlotti, E. and Di Vincenzo, D. (2005), "The audit firm rotation rule: A review of the literature", Social Science Research Network (SSRN). Available at: https://papers.ssrn.com/sol3/papers.cfm?abstract_id=825404 (accessed 22/07/2017).

Cameran, M., Negri, G. and Pettinicchio, A. K. (2015), "The Audit Mandatory Rotation Rule: The State of the Art", Social Science Research Network (SSRN). Available at: https://papers.ssrn.com/sol3/papers.cfm?abstract_id=2596492 (accessed 04/08/2017).

Cameran, M., Prencipe, A. and Trombetta, M. (2016), "Mandatory Audit Firm Rotation and Audit Quality", European Accounting Review, Vol. 25 No. 1, pp. 35-58.

CAQ. (2015), "External Auditor Assessment Tool: A Reference for Audit Committees Worldwide", Center for Audit Quality (CAQ). Available at: http://www.thecaq.org/external-auditor-assessment-tool-reference-audit-committeesworldwide (accessed 31/07/2017).

Chi, W., Huang, H., Liao, Y. and Xie, H. (2009), "Mandatory Audit Partner Rotation, Audit Quality, and Market Perception: Evidence from Taiwan*", Contemporary Accounting Research, Vol. 26 No. 2, pp. 359-391.

CNBC. (2017), "Tax-free no more: Saudi Arabia, UAE to roll out VAT in 2018.", CNBC. CNBC - International Edition, Online, 27 December 2017. Available at: https://www.cnbc.com/2017/12/27/the-associated-press-tax-free-no-more-saudiarabia-uae-to-roll-out-vat-in-2018.html (accessed 31 December 2017). 
Copley, P. A. and Doucet, M. S. (1993), "Auditor tenure, fixed fee contracts, and the supply of substandard single audits", Public Budgeting \& Finance, Vol. 13 No. 3, pp. 23-35.

Daniels, B. W. and Booker, Q. (2011), "The effects of audit firm rotation on perceived auditor independence and audit quality", Research in Accounting Regulation, Vol. 23 No. 1, pp. 78-82.

Daugherty, B. E., Dickins, D., Hatfield, R. C. and Higgs, J. L. (2012), "An Examination of Partner Perceptions of Partner Rotation: Direct and Indirect Consequences to Audit Quality", AUDITING: A Journal of Practice \& Theory, Vol. 31 No. 1, pp. 97-114.

Davis, L. R., Soo, B. S. and Trompeter, G. M. (2009), "Auditor tenure and the ability to meet or beat earnings forecasts", Contemporary Accounting Research, Vol. 26 No. 2, pp. 517-548.

DeAngelo, L. E. (1981), "Auditor size and audit quality", Journal of accounting and economics, Vol. 3 No. 3, pp. 183-199.

DeFond, M. L. and Francis, J. R. (2005), "Audit research after sarbanes-oxley", Auditing: A Journal of Practice \& Theory, Vol. 24 No. s-1, pp. 5-30.

Doward, J. (2018), "Whistleblower suing Ernst \& Young over gold dealings with Dubai firm: Sacked auditor says he was branded a troublemaker after telling bosses of his concerns about the Kaloti group". The Guardian - Business News, Online, 21 January 2018, 00:04. Available at: https://www.theguardian.com/business/2018/jan/21/ernstyoung-whistleblower-suing-gold-audit-dubai (accessed 18/02/2019).

Ebimobowei, A. and Keretu, O. J. (2011), "Mandatory rotation of auditors on audit quality, costs and independence in South-South, Nigeria", International Business Management, Vol. 5 No. 3, pp. 166-172.

European Commission. (2010), "Green Paper - Audit Policy: Lesson from the Crisis". Available at:

http://ec.europa.eu/internal_market/consultations/docs/2010/audit/green_paper_audit en.pdf. (accessed 02/03/2015).

European Commission. (2011), "Summary of Responses - Green Paper - Audit Policy:

Lesson from the Crisis". Available at:

http://ec.europa.eu/finance/consultations/2010/green-paperaudit/docs/summary_responses_en.pdf (accessed 25/07/2017).

Everington, J. (2015), "UAE accountants welcome new auditing law", The National Business News (March 23, 2015). Available at:

https://www.thenational.ae/business/uae-accountants-welcome-new-auditing-law1.12632 (accessed 26/07/2017).

Ewelt-Knauer, C., Gold, A. and Pott, C. P. (2013), "Mandatory Audit Firm Rotation: A Review of Stakeholder Perspectives and Prior Research", Accounting in Europe, Vol. 10 No. 1, pp. 27-41.

Field, A. (2016), An Adventure in Statistics: The Reality Enigma, SAGE, London | California | New Delhi | Singapore.

Field, A. (2018), Discovering Statistics Using IBM SPSS Statistics, SAGE, Los Angeles | London | New Delhi | Singapore | Washington DC | Melbourne.

Firth, M. A., Rui, O. M. and Wu, X. (2012), "Rotate back or not after mandatory audit partner rotation?", Journal of Accounting and Public Policy, Vol. 31 No. 4, pp. 356-373.

Frunza, M.-C. (2019), Value Added Tax Fraud, Routledge, Routledge Research in Finance and Banking Law.

Garcia-Blandon, J. and Argiles-Bosch, J. M. (2017), "The interaction effects of firm and partner tenure on audit quality", Accounting and Business Research, pp. 1-21. 
Gates, S. K., Jordan Lowe, D. and Reckers, P. M. (2006), "Restoring public confidence in capital markets through auditor rotation", Managerial Auditing Journal, Vol. 22 No. 1, pp. 5-17.

Geiger, M. A. and Raghunandan, K. (2002), "Auditor tenure and audit reporting failures", Auditing: A Journal of Practice \& Theory, Vol. 21 No. 1, pp. 67-78.

Grant Thornton. (2015), "The changing role of Audit - White Paper". Grant Thornton (An instinct for growth) in collaboration with ACCA (Think Ahead), 2 June 2015, Published Online, 01 March 2016. Available at: http://www.grantthornton.ae/globalassets/uae/may-2017-onwards/additional-reportsand-thumbnails/the-changing-role-of-audit-uae-perspective.pdf (accessed 01/01/2018).

Halbouni, S. S. (2015), "The Role of Auditors in Preventing, Detecting, and Reporting Fraud: The Case of the United Arab Emirates (UAE)", International Journal of Auditing, Vol. 19 No. 2, pp. 117-130.

Hohenfels, D. (2016), "Auditor tenure and perceived earnings quality", International Journal of Auditing, Vol. 20 No. 3, pp. 224-238.

Ibrahim, M. (2010), "State Audit Institution in United Arab Emirates", International Journal of Law and Management, Vol. 52 No. 6, pp. 464-468.

IESBA. (2016), "Handbook of the Code of Ethics for Professional Accountants". International Federation of Accountants (IFAC), 529 Fifth Avenue, New York, 10017 USA, International Ethics Standards Board for Accountants (IESBA). Available at: https://www.ethicsboard.org/iesba-code (accessed 01/08/2017).

Iskandar, T. M., Rahmat, M. and Ismail, H. (2010), "The relationship between audit client satisfaction and audit quality attributes: Case of Malaysian listed companies", International Journal of Economics and Management, Vol. 4 No. 1, pp. 155-180.

Jackson, A. B., Moldrich, M. and Roebuck, P. (2008), "Mandatory audit firm rotation and audit quality", Managerial Auditing Journal, Vol. 23 No. 5, pp. 420-437.

Johnson, V. E., Khurana, I. K. and Reynolds, J. K. (2002), "Audit-firm tenure and the quality of financial reports", Contemporary accounting research, Vol. 19 No. 4, pp. 637-660.

Kilgore, A. (2007), "CORPORATE GOVERNANCE, PROFESSIONAL REGULATION AND AUDIT QUALITY", Malaysian Accounting Review, Vol. 6 No. 1.

Kline, P. (2013), Handbook of psychological testing, Routledge, London and New York.

Kowaleski, Z. T., Mayhew, B. W. and Tegeler, A. C. (2018), "The Impact of Consulting Services on Audit Quality: An Experimental Approach", Journal of Accounting Research, Vol. 56 No. 2, pp. 673-711.

KPMG. (2014), "Global Anti-Money Laundering Survey". Available at: https://home.kpmg.com/xx/en/home/insights/2014/01/global-anti-money-launderingsurvey.html (accessed 31/07/2018).

Kwon, S. Y., Lim, Y. D. and Simnett, R. (2011), "Mandatory audit firm rotation and audit quality: Evidence from the Korean audit market", SSRN eLibrary.

Myers, J. N., Myers, L. A. and Omer, T. C. (2003), "Exploring the term of the auditor-client relationship and the quality of earnings: A case for mandatory auditor rotation?", The Accounting Review, Vol. 78 No. 3, pp. 779-799.

Ouyang, B. and Wan, H. (2013), "Does Audit Tenure Impair Auditor Independence?

Evidence from Option Backdating Scandals", International Journal of Business and

Social Science, Vol. 4 No. 14, pp. 23-33.

PwC. (2017), "Economic Crime Update - 2017 UAE snapshot". PricewaterhouseCoopers

(PwC). Available at: https://www.pwc.com/m1/en/publications/documents/economiccrime-update-2017-uae-snapshot.pdf (accessed 31/07/2018). 
Ruiz-Barbadillo, E., Gómez-Aguilar, N. and Biedma-López, E. (2006), "Long-term audit engagements and opinion shopping: Spanish evidence", Accounting Forum, Vol. 30 No. 1, pp. 61-79.

Saderuddin, A. and Barghathi, Y. (2018), "The impacts of introduction of VAT on the audit profession and economy in the UAE: Auditors' perspective", Accounting and Management Information Systems, Vol. 17 No. 3, pp. 406-439.

Sambidge, A. (2014), "95\% of MidEast fraud undetected by audits - PwC". Arabian Business, Online, 1 March 2014. Available at: https://www.arabianbusiness.com/95of-mideast-fraud-undetected-by-audits-pwc-540584.html (accessed 18/02/2019).

Staff Report. (2018), "Law for Dubai Financial Audit Authority issued". Gulf News Government, Online, 14 April 2018. Available at: https://gulfnews.com/uae/government/law-for-dubai-financial-audit-authority-issued1.2205144 (accessed 22/02/2019).

Stanley-Smith, J. (2018), "Europe, Middle East and Africa: EMEA corporations restructure as tax planning enters a new era", International Tax Review.

Stanley, J. D. and DeZoort, F. T. (2007), "Audit firm tenure and financial restatements: An analysis of industry specialization and fee effects", Journal of Accounting and Public Policy, Vol. 26 No. 2, pp. 131-159.

Tepalagul, N. and Lin, L. (2015), "Auditor Independence and Audit Quality:A Literature Review", Journal of Accounting, Auditing \& Finance, Vol. 30 No. 1, pp. 101-121.

The CFO. (2015), "The changing role of audit". The CFO Middle East - Profession Watch, Online, 9 September 2015. Available at: http://www.thecfome.com/professionwatch/the-changing-role-of-audit/ (accessed 01/01/2018).

Turner, L. E. (2002), "Hearing on "Accounting and Investor Protection Issues Raised by Enron and Other Public Companies: Oversight of the Accounting Profession, Audit Quality and Independence, and Formulation of Accounting Principles."", U.S. Senate Committee on Banking, Housing, and Urban Affairs, 107th Congress, 2nd Session. (February 26). Washington, DC: Government Printing Office. Available at: https://www.banking.senate.gov/02_02hrg/022602/turner.htm (accessed 31/07/2017).

UAE. (2015), "Federal Law No. 2 of 2015 on Commercial Companies". UAE Government. Available at: http://ejustice.gov.ae/downloads/latest_laws2015/federal_law_2_2015_commercial_c ompanies_en.pdf (accessed 11/09/2017).

USA. (2002), "The Sarbanes-Oxley (SOX) Act of 2002". Available at: http://www.sarbanesoxley-act.biz/SarbanesOxleyAct.htm (accessed 30/07/2017).

Vanstraelen, A. (2000), "Impact of renewable long-term audit mandates on audit quality", European Accounting Review, Vol. 9 No. 3, pp. 419-442.

Venkataraman, V. (2018), "Policing the audit industry needs top billing: The UAE ought to put in place tough regulations to stamp out irregularities". Gulf News - Business, Online, 25 June 2018, 13:39. Available at: https://gulfnews.com/business/analysis/policing-the-audit-industry-needs-top-billing1.2241844 (accessed 18/02/2019).

Zahra, S. A. (2011), "Doing research in the (new) Middle East: Sailing with the wind", Academy of Management Perspectives, Vol. 25 No. 4, pp. 6-21. 